\title{
TRONDHEIM NATURAL RADIOCARBON MEASUREMENTS V
}

\section{REIDER NYDAL, KNUT LÖVSETH, and ODDVEIG SYRSTAD}

Radiological Dating Laboratory,

Norwegian Institute of Technology, Trondheim, Norway

INTRODUCTION

The present date list covers mainly the datings done from 1964 to 1968. Each sample is measured in one of the two counting units described earlier (Nydal, 1965). The background of the counters has been somewhat reduced during the past few years. Counter 2 with an effective volume of $1.5 \mathrm{~L}$ ( $1.9 \mathrm{~L}$ total volume), has a background of 0.9 counts/ min, and a recent standard net count of 19.2 counts $/ \mathrm{min}$. Counter 3 , with an effective volume of $1.1 \mathrm{~L}(1.3 \mathrm{~L}$ total volume), has a background of 2.4 counts/min and a recent standard net count of 14.2 counts/min.

Samples of wood and charcoal are treated with $1 \mathrm{M} \mathrm{HCl}$ and $1 \mathrm{M}$ $\mathrm{NaOH}$. Peat and gyttja are only treated with $1 \mathrm{M} \mathrm{HCl}$. Shells are treated with dilute $\mathrm{H}_{3} \mathrm{PO}_{4}$, and generally 10 to $20 \%$ of the weight is removed in cleaning the surface.

All dates are calculated both in years before 1950 and in the A.D./ B.C. scale. The applied $\mathrm{C}^{14}$ halflife is $5570 \mathrm{yr}$; its standard deviation of $\pm 30 \mathrm{yr}$ is not included in the standard deviation $(1 \sigma)$ of the dating results. Correction for isotopic fractionation is generally performed only for samples with age less than 2000 yr B.P. The NBS recent standard is $95_{\%}^{\circ}$ of the $\mathrm{C}^{14}$ activity in the oxalic acid.

\section{ACKNOWLEDGMENTS}

The authors wish to thank the collectors and submitters of the samples for their colloboration in preparing the manuscript. Special thanks are due Dr. Ragnar Ryhage for making the $\mathrm{C}^{13}$ measurements. Further thanks to Ingegjerd Skjöstad and Elsa Riiser for treating the samples. Financial support from Norges Almenvitenskapelige Forskningsråd is fully acknowledged.

\section{SAMPLE DESCRIPTIONS}

I. GEOLOGIC SAMPLES

1. Glacial events, Troms

A. Norway

\section{T-436. Tromsö shell}

Shells (Astarte elliptica, Arctica [Cyprina] islandica, Chlamys [Pecten] islandicus, and Mya truncata) from gravel pit, Tromsö Airport, $\left(69^{\circ} 42^{\prime} \mathrm{N}\right.$ Lat, $18^{\circ} 55^{\prime} \mathrm{E}$ Long), Troms, Norway. In low Tromsö-Lyngen moraine ridge $S$ end of runway. Broken and whole shells lie in bouldery glaciomarine clay, overlain by $5 \mathrm{~m}$ marine sand and 1 to $3 \mathrm{~m}$ till. Coll. and subm. 1964 by B. G. Andersen, Univ. of Oslo.

\section{T-436A. Tromsö shell, outer fraction (55\%)}




\section{T-436B. Tromsö shell, inner fraction (45\%) $\quad \mathbf{9 5 7 0} \pm 150$}

Comment (B.G.A.): glaciomarine clay and shells date a phase prior to advance in which upper till was deposited. This phase is either early Tromsö-Lyngen phase or immediately prior to it. T-436A and T-436B represent, respectively, $55 \%$ and $45 \%$ of cleaned and surface-treated shell sample. The great difference in age between 436A and 436B suggests considerable contamination of shells by ionic exchange. T-436B is, most likely, minimum age for shells (Andersen, 1968, p. 47).

\section{T-437. Rensaa shell}

$11,650 \pm 220$ 9700 B.c.

Shell fragments (Astarte elliptica, Arctica [Cyprina] islandica, Chlamys [Pecten] islandicus, Mya truncata, and Hiatella [Saxicava] arctica) from gravel pit in submarine-deposited Tromsö-Lyngen end moraine at Rensaa ( $68^{\circ} 41^{\prime} \mathrm{N}$ Lat, $16^{\circ} 55^{\prime} \mathrm{E}$ Long), Troms, Norway. Distinct moraine ridge consists of upper gravelly deltaic sec. at $+68 \mathrm{~m}$ to $45 \mathrm{~m}$, and a middle marine sec. at $+45 \mathrm{~m}$ to $15 \mathrm{~m}$. Shell fragments lie in silty parts of gravelly deltaic foreset sec. Coll. and subm. 1964 by B. G. Andersen.

T-437A. Rensaa shell, outer fraction (35\%)

$10,830 \pm 180$ 8880 B.C.

\section{T-437B. Rensaa shell, inner fraction (65\%) 9700 B.c.}

Comment (B.G.A.): shell fragments are most probably older than host sediments, corresponding in age to lower lying glaciomarine clay, where same species occur in abundance. Great age difference between $\mathrm{T}-437 \mathrm{~A}$ and $\mathrm{T}-437 \mathrm{~B}$ suggests considerable contamination by ionic exchange. T-437B probably represents minimum age of shells (Andersen, 1968, p. 64).

\section{T-438. Rensaa shell}

$11,880 \pm 170$

(average)

Shells (Astarte elliptica, Arctica [Cyprina] islandica, Chlamys [Pecten] islandicus, Mya truncata, and Hiatella [Saxicava] arctica) from bouldery glaciomarine clay at foot of Rensaa moraine $\left(68^{\circ} 41^{\prime} \mathrm{N}\right.$ Lat, $16^{\circ}$ $55^{\prime}$ E Long) Troms, Norway. (See description for T-437). Coll. and subm. 1964 by B. G. Andersen.

\section{T-438A. Rensaa shell, outer fraction (40\%)}

$11,990 \pm 250$ 9040 B.c.

\section{T-438B. Rensaa shell, inner fraction (60\%)}

$$
\begin{gathered}
11,770 \pm 210 \\
9820 \text { в.c. }
\end{gathered}
$$

Comment (B.G.A.): shells were unbroken, and must be of same age as host sediment. They date old phase of Tromsö-Lyngen event or phase prior to this event. Notice agreement between T-438A and $\mathrm{B}$, and $\mathrm{T}$ 436B (Andersen, 1968, p. 64). 
T-511. Bjorelvnes shell

$11,290 \pm 210$

9340 B.C.

Shells (Mya truncata) from foreset bed of raised outwash delta at $+60 \mathrm{~m}$ at Bjorelvnes $\left(69^{\circ} 22^{\prime} \mathrm{N}\right.$ Lat, $18^{\circ} 5^{\prime} \mathrm{E}$ Long) Troms, Norway. Coll. and subm. 1965 by B. G. Andersen.

T-511A. Bjorelvnes shell, outer faction $11,330 \pm 280$

Craction (60\%) 9380 B.c.

T-511B. Bjorelvnes shell, inner fraction (40\%) 9300 B.c.

$11,250 \pm 310$
9300 B.c.
of a Tromsö-

Lyngen end moraine, main part of delta must correspond to this moraine. Shells from slightly higher and lower stratigraphic positions than T-511 have been dated at $10,500 \pm 400 \mathrm{yr}$ (T-50, Radiocarbon, 1959, v. 1, p. 46) and $11,150 \pm 500 \mathrm{yr}$ (T-174, Andersen, 1968, p. 57), respectively.

\section{T-173. Bröstadbotn shell}

$10,100 \pm 500$

Shells (Portlandia arctica and Macoma calcarea) from rd. cut 1 $\mathrm{km} \mathrm{E}$ of Bröstad $\left(69^{\circ} 5^{\prime} \mathrm{N}\right.$ Lat, $17^{\circ} 40^{\prime} \mathrm{E}$ Long) Troms, Norway. From glaciomarine clay below $4 \mathrm{~m}$ gravel and sand in outwash delta, at +62 $\mathrm{m}$ to $68 \mathrm{~m}$. Tromsö-Lyngen end moraine lies $1 \mathrm{~km}$ distant. Coll. and subm. by B. G. Andersen. Comment (B.G.A.): outwash and possibly clay correspond to Tromsö-Lyngen moraine. Early Younger Dryas age for shells was expected. Sample consisted of thin shells, which could have been slightly contaminated by ionic exchange (Andersen, 1968, p. 61).

\section{T-174. Bjorelvnes shell}

$11,150 \pm 500$

Shells (Macoma calcarea) from foreset beds of raised outwash delta at $+60 \mathrm{~m}$ at Bjorelvnes $\left(69^{\circ} 22^{\prime} \mathrm{N}\right.$ Lat, $18^{\circ} 5^{\prime} \mathrm{E}$ Long) Troms, Norway. Coll. and subm. by B. G. Andersen. Comment (B.G.A.): as outwash delta lies in front of Tromsö-Lyngen end moraine, main part of delta must correspond with this moraine. Shells from higher-lying foreset beds within delta were dated at $10,500 \pm 400 \mathrm{yr}$ (T-50, Radiocarbon, 1959, v. 1, p. 77) and 11,290 \pm 210 (T-511, Andersen, 1968, p. 57).

2. Various moraines, Troms

\section{T-490. Sandstrand shell}

$$
12,310 \pm 100
$$

(average)

Shells (Mya truncata) from gravel pit at $+70 \mathrm{~m}$ to $78 \mathrm{~m}$ at Sandstrand $\left(68^{\circ} 40^{\prime} \mathrm{N}\right.$ Lat, $16^{\circ} 45^{\prime} \mathrm{E}$ Long) Troms, Norway. Broken and whole shells lie in bouldery gravel, $1.5 \mathrm{~m}$ thick overlying marine sand with boulders. Ca. $5 \mathrm{~m}$ well-sorted beach sand overlies gravel, which must be a near-shore deposit. Some large boulders within gravel are striated; probably ice rafted. Coll. and subm. 1964 by B. G. Andersen.

T-490A. Sandstrand shell, outer fraction (31\%)

$12,340 \pm 160$

10,390 B.c. 
T-490B. Sandstrand shell, middle fraction (34\%)

\section{T-490C. Sandstrand shell, inner fraction} $(35 \%)$

\section{$12,470 \pm 160$} 10,520 в.C.

$12,110 \pm 160$

10,160 в.c.

Comment (B.G.A.): since pit is located only $200 \mathrm{~m}$ outside Langnes end moraine, boulders within gravel were probably rafted on icebergs from Langnes ice front. Shells and boulder-gravel probably date Langnes moraine, which corresponds to Skarpnes event (Andersen, 1968, p. 33).

\section{T-509. Ulsfjord shell}

$11,200 \pm 190$ 9250 B.C.

Shells (Macoma calcarea, Mya truncata, and Hiatella [Saxicava] arctica) from Svensby, Ulsfjord $\left(69^{\circ} 40^{\prime} \mathrm{N}\right.$ Lat, $19^{\circ} 50^{\prime} \mathrm{E}$ Long) Troms, Norway. Shells lie in glaciomarine bouldery clay exposed in gully at ca. +40 m. Coll. and subm. 1965 by B. G. Andersen. Comment (B.G.A.): lying immediately outside Skarpnes end moraine and ca. $5 \mathrm{~km}$ outside Tromsö-Lyngen end moraine, clay could correspond to either of the 2 events, or to melting between the 2 events (Andersen, 1968, p. 30).

\section{T-510. Balsfjord shell}

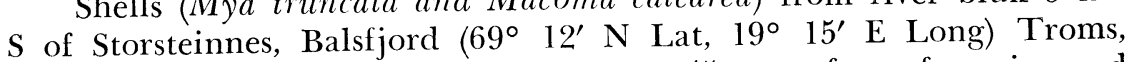
Norway. Shells lie in marine clay at ca. $+45 \mathrm{~m}$ at foot of marine end moraine. Coll. and subm. 1965 by B. G. Andersen.

\section{T-510A. Balsfjord shell, outer fraction (61\%) 7240 B.C. \\ $\quad 9100 \pm 150$ \\ T-510B. Balsfjord shell, inner fraction (39\%) $\mathbf{7 1 5 0}$ B.c.}

Comment (B.G.A.): end moraine is correlated with Stordal event. Glay bed continues into moraine, and shells date phase of end moraine and Stordal events (Andersen, 1968, p. 82).

\section{Gratangen shell series}

Shells (Mya truncata, Hiatella [Saxicava] arctica, and Macoma calcarea) from river bluff at Gratangen $\left(68^{\circ} 40^{\prime} \mathrm{N}\right.$ Lat, $17^{\circ} 45^{\prime} \mathrm{E}$ Long) Troms, Norway, in sand and silt at $+25 \mathrm{~m}$ to $30 \mathrm{~m}$, overlain by $10-\mathrm{m}$ sec. glaciomarine (till-like) gravelly sediments. Marine silt and sand occur up to $+75 \mathrm{~m}$. Coll. and subm. 1965 by B. G. Andersen.
$\begin{array}{lll}\text { T-512A. Gratangen shell (I), outer fraction } & 9560 \pm 120 \\ (40 \%) & \mathbf{7 6 1 0 ~ B . C . ~}\end{array}$ $(40 \%)$
T-512B. Gratangen shell (I), inner fraction $(60 \%)$
$9470 \pm 160$ 7520 B.C.




\section{T-630. Gratangen shell (II)}

Comment (B.G.A.); gravelly, till-like sediments must have been deposited partly in contact with glacier or immediately in front of glacier. Located a few $\mathrm{m}$ inside marine end moraine, these sediments are probably related to moraine. Sand-silt beds and shells probably date phase shortly prior to glacier advance at which end moraine was deposited; it has been correlated with a Stordal event (Andersen, 1968, p. 86).

\section{T-631. Oldervikdal shell}

$11,550 \pm 190$

Shells (Mya truncata, Hiatella arctica, and Macoma calcarea) from glaciomarine clay $2 \mathrm{~km} \mathrm{~W}$ of Oldervik village $\left(69^{\circ} 45^{\prime} \mathrm{N}\right.$ Lat, $19^{\circ} 40^{\prime} \mathrm{E}$ Long) Troms, Norway. Clay was exposed at foot of marine terrace at $+52 \mathrm{~m}$ to $54 \mathrm{~m}$. Coll. and subm. 1966 by B. G. Andersen. Comment (B.G.A.): date shows valley was ice-free in Alleröd time and 52- to 54-m terrace was formed at or after mid-Alleröd time (Andersen, 1968, p. 43).

\section{T-6.22. Örlandsmorenen}

$7620 \pm 130$

Shell and shell fragments from moraine ridge Uthaug-Brekstad, Uthaug, Örlandet $\left(63^{\circ} 43^{\prime} \mathrm{N}\right.$ Lat, $9^{\circ} 37^{\prime} \mathrm{E}$ Long) S. Tröndelag, Norway. Found in clay 0.30 to $1.40 \mathrm{~m}$ deep. Coll. and subm. 1967 by J. L. Sollid, Univ. of Oslo (Sollid, 1965; Holtedahl, 1928; Gjessing, 1966).

\section{Driftwood, Northern Norway}

\section{T-504. Skjervik}

Driftwood log (Larix) from Skjervik, Nord-Kvalöy, Karlsöy $\left(70^{\circ} 10^{\prime}\right.$ $\mathrm{N}$ Lat, $19^{\circ} 14^{\prime} \mathrm{E}$ Long) Troms, Norway. In peat at $+5.42 \mathrm{~m}$ and $0.5 \mathrm{~m}$ deep. Coll. 1964 and subm. 1965 by H. P. Hansen, Inst. of Geog., Univ. of Oslo (P. T. Tromsö off. lærerskole, Tromsö). Comment (H.P.H.): according to shoreline diagrams (Hansen, 1966, Pl. 1; Marthinussen, 1960, Pl. 16) $\log$ lies between levels $\mathrm{N}_{2}$ (ca. $2450 \mathrm{yr}$ B.P.) and $\mathrm{N}_{4}$ (ca. $4100 \mathrm{yr}$ B.P.; Marthinussen, 1962, Pl. 1 and Pl. 2). Dating result thus agrees with expectation.

\section{T-505. Bekkestrand}

$4130 \pm 100$

Driftwood $\log$ (Larix) from Bekkestrand, Vannöy, Karlsöy $\left(70^{\circ} 08^{\prime}\right.$ $\mathrm{N}$ Lat, $19^{\circ} 40^{\prime} \mathrm{E}$ Long) Troms, Norway. In peat at +6.75 to $7.15 \mathrm{~m}$ and 1.0 to $1.5 \mathrm{~m}$ deep. Coll. 1964 and subm. 1965 by H. P. Hansen. Comment (H.P.H.): $\log$ lies in peat bog at level near height of $\mathrm{N}_{4}$-line (Hansen, 1966, Pl. 1, Marthinussen, 1960, Pl. 16). Dating results (T-504 and T-505) seem to prove position of neoglacial lines; also that relation between height of each of these lines and Main line $\left(\mathrm{S}_{\mathrm{o}}\right)$ is same in N Troms as in W Finnmark. 


\section{Various moraines, Southern Norway}

\section{T-424. Ra-moraine at Rygge}

$10,760 \pm 200$

8810 B.C.

Shells (Portlandia arctica) from a well ca. $4 \mathrm{~km}$ E of Rygge $\left(59^{\circ} 22^{\prime}\right.$ $\mathrm{N}$ Lat, $10^{\circ} 42^{\prime} \mathrm{W}$ Long) Östfold, Norway. In glaciomarine clay ca. $4.5 \mathrm{~m}$ deep. Numerous boulders lie within clay, and beach-washed boulder layer covers surface. Located on distal slope of distinct marine Ra End moraine. Coll. and subm. 1963 by B. G. Andersen, Univ. of Oslo, and G. W. Holmes, U.S. Geol. Survey. Comment (B.G.A.): the clay corresponds to the moraine. Many shells were paired and must be same age as clay and moraine (Andersen, 1968, p. 75).

\section{T-425. Ra-moraine near Sarpsborg}

$10,080 \pm 160$

8130 в.c.

Shells (Portlandia arctica, Macoma calcarea, Hiatella [Saxicava] arctica) from gravel pit ca. $3 \mathrm{~km} \mathrm{~W}$ of Sarpsborg $\left(59^{\circ} 18^{\prime} \mathrm{N}\right.$ Lat, $11^{\circ}$ $4^{\prime}$ E Long) Östfold, Norway. Pit lies next to asphalt plant on crest of marine Ra-moraine. Many unbroken shells coll. from glaciomarine bouldery clay. Coll. and subm. 1963 by B. G. Andersen and G. W. Holmes. Comment (B.G.A.): stratigraphy suggests clay and shells deposited during late phase, or melting phase of Ra glacier (Andersen, 1968, p. 75).

\section{T-426. Ra-moraine near Sandef jord}

$10,650 \pm 150$ 8700 в.c.

Shells (Portlandia arctica, Macoma calcarea, and Hiatella [Saxicava] arctica) from gravel pit $5 \mathrm{~km} \mathrm{SW}$ of Sandefjord $\left(59^{\circ} 6^{\prime} \mathrm{N} \mathrm{Lat,} 10^{\circ} 5^{\prime} \mathrm{E}\right.$ Long) Vestfold, Norway. Pit is on proximal slope at foot of Ra-moraine. In bouldery glaciomarine clay, overlain by folded, stratified marine silt and till. Coll. and subm. 1963 by B. G. Anderson and G. W. Holmes. Comment (B.G.A.): all shells are unbroken; must be same age as clay. Shells and clay date $\mathrm{Ra}$ phase prior to advance at which upper till was deposited (Andersen, 1968, p. 75).

\section{Various geologic samples}

\section{Blomvåg series, Hordaland}

Lacustrine sediments from Dale at Blomvåg, Blomöy $\left(60^{\circ} 30^{\prime} \mathrm{N}\right.$ Lat, $4^{\circ} 53^{\prime}$ E Long) Hordaland, Norway. Coll. with a piston borer (diam. $0.045 \mathrm{~m}$ ) of type described by J. Olsson (1925). Coll. and subm. 1966 and 1967 by J. Mangerud, Univ. of Bergen. Comment (J.M.): from 1941 to 1942, organic sediments were found below till at Blomvåg (Undås, 1942; Holtedahl, 1960). Two earlier radiocarbon dates, T-138 and T-139 (Radiocarbon, 1960, v. 2, p. 88) indicate Bölling age of sediments. Present dates are from bog near locality mentioned, stratigraphically situated above till. Dates confirm till was deposited by ice advance during older Dryas time, and Blomvåg was not covered later by ice (Mangerud, 1968). 
T-623. Fine-detritus gyttja, 2.04 to $2.17 \mathrm{~m}$ deep 7390 в.c.

Coll. just above clay $0.15 \mathrm{~m}$ thick. Comment (J.M.): corresponds to Pre-Boreal in pollen diagram, and probably lower part of Boreal.

T-624. Clay gyttja, 2.22 to $2.29 \mathrm{~m}$ deep

$10,940 \pm 180$

Coll. just below clay layer (see T-623). Comment (J.M.): corresponds to end of Alleröd in pollen diagram.

T-625. Clay gyttja, 2.36 to $2.48 \mathrm{~m}$ deep

$11,070 \pm 190$

Comment (J.M.): upper part of Alleröd in pollen diagram.

\section{T-672. Clay gyttja, 2.85 to $2.95 \mathrm{~m}$ deep \\ $12,070 \pm 180$}

Deepest part of organic sediments, 0 to $0.10 \mathrm{~m}$ above gray

\section{T-594. Vindenes}

$10,970 \pm 180$ 9020 B.c.

Shells (Mya truncata) from Late-glacial clay at Vindenes, Fusa $\left(60^{\circ}\right.$ $9^{\prime} \mathrm{N}$ Lat, $5^{\circ} 38^{\prime} \mathrm{E}$ Long) Hordaland, Norway. Clay extends up to $+5 \mathrm{~m}$. Coll. 1920 by C. K. Kolderup; subm. 1966 by J. Mangerud. Comment (J.M.): date indicates late Alleröd age of Vindenes clay. No evidence of post-clay ice advance is described (Kolderup, 1908). If assumption (op. cit.) is right, moraines of Younger Dryas age must be situated $\mathrm{E}$ of Vindenes.

\section{T-580. Lepsöyvann, Hordaland}

$8380 \pm 180$

Lacustrine (fine detritus) gyttja from Lake Lepsöyvann $+0.20 \mathrm{~m}$, Os $\left(60^{\circ} 9^{\prime} \mathrm{N}\right.$ Lat, $5^{\circ} 24^{\prime} \mathrm{E}$ Long) Hordaland, Norway. Coll. with Hiller borer at 9.56 to $9.61 \mathrm{~m}$ depth just above marine clay. Coll. and subm. by J. Mangerud. Comment (J.M.): dates $\mathrm{C}^{14}$ age of isolation of basin from sea. Corresponds to Corylus maximum pollen diagram.

\section{T-645. Langeland, Sogn og Fjordane}

$10,470 \pm 170$

Shells (Saxicava pholadis, Mya truncata, and Macoma calcarea) from glaciomarine clay, Langeland, Nordfjordeid, $\left(61^{\circ} 55^{\prime} \mathrm{N}\right.$ Lat, $6^{\circ} 01^{\prime} \mathrm{E}$ Long), Sogn og Fjordane, Norway. Coll. at 10 to $12 \mathrm{~m}$ depth (Kaldhol, 1912; Rekstad, 1905). Coll. 1904 by J. Rekstad; subm. 1967 by O.W. Fareth, Univ. of Bergen. Comment (O.W.F.): recent investigations in Nordfjord, W Norway (ms. in prep.), indicate several glacial substages, of which the most prominent is Main substage. During that substage long outlet glaciers from ice sheet, occupied basins of Lake Hornindalsvannet and Nordfjord E of Anda, and filled the valley system of Breim and Gloppen. This is indicated by prominent lateral and terminal moraines and a distinctive shoreline in fjord outside the moraines. 
Dated shells were just outside outwash delta built in front of glacier occupying Lake Hornindalsvannet. Shell-bearing clay seems to have been deposited in early phase of this substage, probably late Younger Dryas (cf. also T-616, below). Expected age: 10,000 to 11,000 yr.

\section{T-616. Oldevannet, Sogn og Fjordane}

Shells (Cyprina islandica and Cardium echinatum) from marine clay at $+31 \mathrm{~m}$ at $\mathrm{E}$ shore of Lake Oldevannet, Haaheim, Olden, Stryn $\left(61^{\circ}\right.$ $47^{\prime} \mathrm{N}$ Lat, $6^{\circ} 50^{\prime}$ E Long) Sogn og Fjordane, Norway. Coll. 1965 by I. Beinnes; subm. 1967 by O. W. Fareth. Comment (O.W.F.): shells, ca. 2 $\mathrm{km}$ from Eide moraine ( $\mathrm{N}$ end of Lake Oldevannet), are younger than this moraine (Kahldhol, 1912, p. 32, 54). Yet Eide moraine must be younger than Main substage (cf. T-645), when ice front was nearly $50 \mathrm{~km}$ further to $\mathrm{W}$, and lateral moraines indicated ice thickness at Eide $>1100 \mathrm{~m}$. Eide substage, possibly including moraines in front of Lakes Strynsvann and Sanddalsvann (Kaldhol, 1912, p. 53), is probably Pre-Boreal.

\section{T-608. Kosmoli, Nordland}

$2740 \pm 90$

790 B.C.

Regenerative Sphagnum peat from ombrogenous bog E of Kykkelsvann, Skjerstad $\left(67^{\circ} 02^{\prime} \mathrm{N}\right.$ Lat, $15^{\circ} 01^{\prime} \mathrm{E}$ Long) Nordland, Norway. Coll. with Hiller borer from bottom of bog, at 1.60 to $1.66 \mathrm{~m}$ depth, just above basal sand. Coll. and subm. 1966 by D. Moe and U. Hafsten. Comment: T-608 dates 1st appearance (absolute pollen boundary) of spruce in pollen profile, ascribed to long-distance pollen transport from N Sweden (Moe, 1968).

\section{T-634. Arstadmyrene, Nordland}

$$
1080 \pm 60
$$

\section{A.D. 870}

(average)

Peat from bog in Arstad, Beiarn $\left(67^{\circ} 02^{\prime} \mathrm{N}\right.$ Lat, $14^{\circ} 35^{\prime} \mathrm{E}$ Long) Nordland, Norway. Coll. with Hiller borer from Eriophorum vaginatum peat at base of bog, at 0.80 to $0.90 \mathrm{~m}$ depth, on top of sand. Coll. 1966 and 1967 by D. Moe; subm. 1967 by D. Moe and U. Hafsten. Comment: T-634A and T-634B were taken from same peat layer at same depth, but T-634A may have been contaminated because sampling was done in bad weather.

T-634B would appear to be more reliable and dates pronounced increase in pollen of cultivated plants in this diagram (Moe, 1968).

T-634 A.

$1010 \pm 70$

T-634 B.

$1140 \pm 80$

\section{Sjetnemyr series, Trondheim}

Peat from Bog Sjetnemyr, Trondheim $\left(63^{\circ} 21^{\prime} \mathrm{N}\right.$ Lat, $10^{\circ} 23^{\prime} \mathrm{E}$ Long) Sör-Tröndelag, Norway. Coll. with Hiller borer from depth 4.30 to $4.40 \mathrm{~m}$. Coll. 1967 by Kari Vik Knudsen; subm. 1967 by K. V. Knudsen and U. Hafsten. 


\section{T-680. Sjetnemyr I}

$6040 \pm 90$

T-681. Sjetnemyr II

4090 B.C.

Comment: T-680 dates very abrupt rise in most warmth-demanding

$8370 \pm 90$

6420 B.c. tree species in this region, viz. elm and hazel, and sudden decline in preceding maximum of alder curve. At the same time there is an obvious increase in forest density, confirming that phytogeographical optimum in Tröndelag took place during Late Atlantic. T-681 dates dark layer, which marks transition from marine to fresh-water conditions, i.e., date at which this site in Tröndelag (ca. $+160 \mathrm{~m}$ ) became isolated from sea. Date also indicates that high birch and low pine values of pollen spectra near base of diagram, seemingly Pre-Boreal, are actually Boreal (Knudsen, 1969, ms. in prep.).

\section{Flöytmyr series, Akershus}

Samples coll. with Hiller borer from same profile in former lake underlying Flöytmyr bog at $+192 \mathrm{~m}$ in Bærum (59 $59^{\circ} \mathrm{N}$ Lat, $10^{\circ} 37^{\prime}$ E Long) Akershus, Norway. Coll. and subm. 1967 by U. Hafsten.

\section{T-657. Flöytmyr I, nekron mud}

$9150 \pm 150$

Coll. 5.50 to $6.50 \mathrm{~m}$ below lake surface, just above basal marine nekron clay mud.

\section{T-658A. Flöytmyr II, charcoal}

$3780 \pm 100$

Coll. 2.05 to $2.10 \mathrm{~m}$ below lake surface.

\section{T-658B. Flöytmyr II, Sphagnum peat}

1830 B.C.

Coll. 2.05 to $2.10 \mathrm{~m}$ below lake surface. Comment (U.H.): T-657 confirms pollen-analytic dating made in 1956 of 1) change from birch to pine dominance and contemporaneous immigration of hazel at PreBoreal/Boreal zone boundary, and 2) time at which this site (192 m) became isolated from sea. T-658A and T-658B are from start of marked agricultural clearance phase in pollen diagram, which Hafsten (1956) referred to the Late Neolithic (Flint Dagger period) expansion of agriculture. Date fully confirms this hypothesis. Charcoal was sorted out from surrounding peat and the 2 samples dated separately. Results are in good agreement, being within standard deviation, showing that both types of material are equally good for dating purposes.

\section{Röyrtjönn series, Lista}

Nekron mud coll. with Hiller sampler from above and below marine transgression layer in small lake, Röyrtjönn, ca. $+7 \mathrm{~m}$, near Farm Vollmona, Lista $\left(58^{\circ} 05^{\prime} \mathrm{N}\right.$ Lat, $06^{\circ} 48^{\prime} \mathrm{E}$ Long) Vest-Agder, Norway. Coll. and subm. 1966 by U. Hafsten. 


\section{T-635. Röyrtjönn A}

Coll. 2.65 to $2.78 \mathrm{~m}$ below surface, above transgression layer.

\section{T-636. Röyrtjönn B}

$6770 \pm 150$

Coll. 2.80 to $3.00 \mathrm{~m}$ below surface, below transgression layer. Comment (U.H.): samples date Tapes transgression during its maximum phase, coinciding in pollen diagram with major expansion of mixed oak forest. They also confirm archaeologic evidence of early Stone age, temporary (hunting) settlements in this area which were occupied at a time when shoreline lay higher than at present $(7 \mathrm{~m})$ and there was abundant game to be found in shallow lakelets and lagoons nearby which would also agree with high percentage of grass pollen in pollen profile.

\section{Vasstöl series, Suldal}

Peat from bog at $+733 \mathrm{~m}$, below old settlement sites near Vasstölvatn lake, Suldal (59 $49^{\circ} \mathrm{N}$ Lat, $06^{\circ} 52^{\prime} \mathrm{E}$ Long) Rogaland, Norway. Coll. and subm. 1965 by U. Hafsten.

\section{T-520. Vasstöl A}

$5870 \pm 100$

Coll. at 1.63 to $1.75 \mathrm{~m}$ below lake surface.

T-521. Vasstöl B

3920 в.c.

$3700 \pm 100$

\section{B.c.}

Coll. at 0.91 to $0.94 \mathrm{~m}$ below lake surface. Comment (U.H.): 2 samples date lower and upper alder maxima of pollen diagram, intervening minimum representing climatic deterioration affecting subalpine region during Late Atlantic and early Sub-Boreal periods.

\section{Ullshelleren series, Röldal}

Eriophorum vaginatum peat from profile in bog at $+700 \mathrm{~m}$ in Valldalen (now site of hydro-electric reservoir), Röldal (59 $54^{\prime} \mathrm{N}$ Lat, $06^{\circ} 55^{\prime}$ E Long) Hordaland, Norway. Coll. and subm. 1964 by U. Hafsten.

\section{T-447. Ullshelleren A}

$$
2330 \pm 90
$$

Coll. at 0.82 to $0.85 \mathrm{~m}$ below surface, just above minerogeneous peat layer.

T-448. Ullshelleren $B$

$2950 \pm 100$

1000 B.c. layer.

Coll. at 0.97 to $1.00 \mathrm{~m}$ below surface, just below minerogeneous peat

T-449. Ullshelleren $\mathrm{C}$

$8140 \pm 140$

Coll. at 3.10 to $3.13 \mathrm{~m}$ below surface, just above basal minerogeneous peat layer. Comment (U.H.): T-447 and T-448 confirm evidence for agriculture in subalpine region shown in pollen diagram during Late Sub- 
Boreal (Bronze age) period with contemporary (2nd) maximum in alder curve.

$\mathrm{T}$-449 dates change from birch to pine dominance in pollen diagram, change which at lower alts occurs $>1000 \mathrm{yr}$ earlier (Hafsten, 1965).

\section{Övstebö series, Aurland}

Pine wood (T-609) and overlying peat (T-610) in bog at $+800 \mathrm{~m}$, ca. $1 \mathrm{~km} \mathrm{E}$ of övstebö tourist hut, Aurland $\left(60^{\circ} 49^{\prime} \mathrm{N}\right.$ Lat, $07^{\circ} 31^{\prime} \mathrm{E}$ Long) Sogn og Fjordane, Norway. Coll. and subm. 1966 by U. Hafsten.

T-609. Övstebö A, pine wood

Coll. at $0.40 \mathrm{~m}$ below surface.

T.610. Övstebö B, peat

Coll. at $0.35 \mathrm{~m}$ below surface. Comment (U.H.): pine stump layer, dated by $T-609$, shows that despite its absence at this alt today, pine could grow here during Late Roman period. T-610 may indicate subsequent deterioration of climate during Migration period.

\section{T-412. Jettegryte, Flåmsdalen}

$9300 \pm 300$

7350 B.c.

Nekron mud coll. with Hiller sampler $0.10 \mathrm{~m}$ above base of 5 -m-deep organic deposit in pothole on Furuberget, a rocky promontory in lower Flåmsdalen valley, Aurland $\left(60^{\circ} 45^{\prime} \mathrm{N}\right.$ Lat, $07^{\circ} 07^{\prime} \mathrm{E}$ Long) Sogn og Fjordane, Norway. Coll. and subm. 1963 by U. Hafsten. Comment (U.H.): date shows that this part of valley was free of ice before 7000 B.c. and that high birch and low pine values of pollen spectra in lower part of diagram, seemingly Pre-Boreal, are, in fact, Boreal (Hafsten, 1965; Klovning and Hafsten, 1965).

\section{T-662. Gjördöla, Trollheimen}

$5340 \pm 120$

3390 B.c.

Pine wood from stump layer, at $2.5 \mathrm{~m}$ depth, in gully eroded by Gjördöla stream through bog at ca. $+750 \mathrm{~m}$, Oppdal $\left(62^{\circ} 43^{\prime} \mathrm{N}\right.$ Lat, $09^{\circ}$ 25' E Long) Sör-Tröndelag, Norway. Coll. and subm. 1967 by U. Hafsten. Comment (U.H.): alder pollen maximum in dated sample agrees with original pollen-analytic conclusion that this maximum falls within Atlantic.

\section{T-743. Hensmoen}

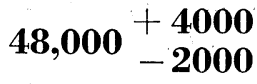

Tree stump of spruce from North Hen sandpit at ice-marginal delta Hensmoen-Jytmoen, Ringerike $\left(60^{\circ} 14^{\prime} \mathrm{N}\right.$ Lat, $10^{\circ} 37^{\prime} \mathrm{E}$ Long) Buskerud, Norway. Sample was imbedded in sorted sand, 12 to $15 \mathrm{~m}$ below ground surface which is about upper marine limit, +203 m. Sec. was $25 \mathrm{~m}$ high, based on bedrock threshold. Lower $10 \mathrm{~m}$ consisted predominantly of bedded, stone-free sand; upper part had more pronounced bedding with small, rounded stones (Gjessing, 1966; Holmsen, 
1955; Nygård, 1969; Sollid, 1969). Coll. 1966 by L. Kjemperud, Hen; subm. 1968 by T. Nygård, Univ. of Oslo.

\section{Buevannet series, Finnmark}

Peat from $+195 \mathrm{~m}$ at Buevannet, Berlevåg $\left(70^{\circ} 33^{\prime} \mathrm{N} \mathrm{Lat}\right.$, $29^{\circ} 4^{\prime} \mathrm{E}$ Long) Finnmark, Norway. Coll. 1962; subm. 1965 by Rauno Ruuhijärvi, Dept. of Botany, Univ. of Helsinki.

\section{T-495. Buevannet (XVI/1)}

0.50 to $0.60 \mathrm{~m}$ below surface.

\section{T-496. Buevannet (XVI/2)}

0.95 to $1.00 \mathrm{~m}$ below surface.

\section{T-497. Buevannet (XVI/3)}

$$
\begin{aligned}
& 1130 \pm 100 \\
& \text { A.D. } 820 \\
& 2510 \pm 90 \\
& 560 \text { B.C. }
\end{aligned}
$$

1.95 to $2.00 \mathrm{~m}$ below surface. Comment (R.R.): T-497 is beginning of paludification in this mire. T-496 is probably age of climatic deterioration in this dist. It can be seen in small absolute arboreal pollen frequency in pollen diagram.

\section{T-498. Russeelvdalen, Finnmark}

$3390 \pm 100$

Carex peat from $+75 \mathrm{~m}$ and 0.65 to $0.70 \mathrm{~m}$ below surface in Russeelvdalen, Måsöy $\left(70^{\circ} 33^{\prime} \mathrm{N}\right.$ Lat, $24^{\circ} 50^{\prime} \mathrm{E}$ Long) Finnmark, Norway. Coll. 1962; subm. 1965 by R. Ruuhijärvi. Comment (R.R.): Pinus (silvestris) pollen maximum in Sub-Boreal period. Sample probably gives age of Pinus in its northernmost localities at Porsanger fjord.

\section{Natvatn series, Finnmark}

Sphagnum peat from $+300 \mathrm{~m}$ at Natvatn, Karasjok $\left(69^{\circ} 40^{\prime} \mathrm{N}\right.$ Lat, $25^{\circ} 15^{\prime}$ E Long), Finnmark, Norway. Coll. 1962; subm. 1965 by R. Ruuhijärvi.

\section{T-493. Natvatn (XII/1)}

$1190 \pm 80$

0.40 to $0.50 \mathrm{~m}$ below surface.

$$
\text { A.D. } 760
$$

\section{T-494. Natvatn (XII/2)}

$6690 \pm 160$ 4740 в.c.

1.35 to $1.45 \mathrm{~m}$ below surface. Comment (R.R.): according to pollen diagram, T-494 indicates coming of Pinus silvestris to its present forest limit after Ice age. Paludification in this mire is ca. 2000 yr older. T-493 indicates age of Sub-Atlantic maximum of Picea abies pollen in this dist.

\section{Ice-cored moraine ridges in Jotunheimen}

Various samples of organic fragments from ice in end-moraine system at Gråsubreen, Jotunheimen (61 $41^{\prime} \mathrm{N}$ Lat, $8^{\circ} 37^{\prime} \mathrm{E}$ Long), Norway. Stratigraphic position of each sample has been described (Östrem, 1965, p. 5). Ca. $100 \mathrm{~kg}$ ice in each ice core was applied for each sample. Ice was melted and, except for rocks and pebbles, enclosed organic material 
was left for sedimentation. Coll. and subm. 1962 and 1963 by Gunnar Östrem, Norwegian Water Resources and Electricity Bd., Oslo. Comment (G.ö.): this ice was also dated by Tritium (St-1259 to 1272, östrem, 1964), and ages were $<50$ years. Probably the discrepancy results from windblown humus particles of similar material which is already quite old when deposited on the snowbank (Östrem, 1965).

T.405. Gråsubreen, humus

Modern

Sample from upper part of ground-moraine sediment outside moraine system. Comment: $\mathrm{T}-405$ had $\mathrm{C}^{14}$ excess of $4.0 \pm 1.0 \%$ above recent standard, and is consequently influenced by atomic bomb.

\section{T-406. Gråsubreen, humus}

$8350 \pm 120$

6400 B.C.

Sample from below surface layers in ground moraine (at ca. 0.20 depth). Sieved through $0.5 \mathrm{~mm}$ mesh to remove possible plant fragments. Comment (G.ö.): surprisingly great age shows that in high-mountain climate, humus decomposes slowly or not at all. (See also St. 1535 to 1537, Radiocarbon, 1965, v. 7, p. 289).

\section{T-373. Gråsubreen, moss and buried rock}

$720 \pm 170$

Moss from rock completely buried in ice core, from which T-356B was coll. Comment (G.ö.): rock was covered with lichen and mosses. Discrepancy between ice dating result $(1300 \pm 100)$ and age of moss is believed to originate from wind-blown older particles, possibly humus. Contrary to N Sweden series (see below) no graphite or carboniferous material were present; no corrections for "dead" carbon should be necessary. However, as humus from the vicinity can yield great ages (St-1364 to 1367 , Radiocarbon, 1965 , v. 7, p. 288) it appears that contamination by such particles increases ages by ca. 1000 yr (see T-397 below).

T-356A. Gråsubreen, Pit 3

$2370 \pm 190$

420 B.C.

Ice from outermost moraine ridge. Compare with T-285 (Radiocarbon, 1962, v. 4, p. 173).

T-356B. Gråsubreen, Pit 3

$1300 \pm 100$

Compare with T-273 below.

T-357. Gråsubreen, Pit 0

A.D. 650

$3780 \pm 150$

1830 B.C.

Sample obtained from one of many ridges in same moraine system. (For location, see östrem, 1965, p. 5).

T-371. Gråsubreen, Pit K

$4060 \pm 170$

T-372. Gråsubreen, $P$ it $M$

2110 B.C.

$6770 \pm 270$

4820 в.C. 


\section{T-374A. Gråsubreen, Pit R}

T-397. Gråsubreen, snowbank

A 500-kg ice sample was taken from ice within permanent snowbank in front of moraine.

\section{B. Sweden}

\section{Ice-cored moraine series in Northern Sweden}

Organic detritus matter from ice core in end moraine system in front of 2 corrie glaciers in Swedish Lapland ( $67^{\circ} 59^{\prime} \mathrm{N}$ Lat, $18^{\circ} 25^{\prime} \mathrm{E}$ Long, and $67^{\circ} 55^{\prime} \mathrm{N}$ Lat, $18^{\circ} 39^{\prime} \mathrm{E}$ Long), Sweden. Comment (G.Ö.): based upon seismic soundings, geo-electric surveys, and air-photo interpretation, it is thought that several large end moraines in Kebnekaise area contain ice cores (Östrem, 1961, 1965). Crystallographic studies show that, in many cases, ice originates from old snowbanks exposed to free atmosphere before being buried by till of later glacier advances. Age of buried, previously air-borne organic particles will be maximum for this glacier advance and formation of end moraine.

\section{T-345A. Vaktposten glacier, Pit A}

$3800 \pm 110$ 1850 B.C.

Ca. $150 \mathrm{~kg}$ ice near bottom of pit was melted and organic material extracted by sedimentation.

\section{T-345B. Vaktposten glacier, Pit A}

$1250 \pm 110$

Similar to T-345A, but taken at higher elev. in pit. Comment (G.Ö.): some contamination of modern reindeer hair makes results doubtful. Age differences are due to variation in depth. Similar differences are found in modern snowbanks (Östrem, 1965, p. 7).

\section{T-346. Tarfala glacier, Pit C}

$16,420 \pm 450$

Sample similar to T-345A. By sedimentation it was obtained ca. $480 \mathrm{~g}$ fine-grained mixture of organic particles and silt. This gave by combustion $2.0 \mathrm{~L} \mathrm{CO}_{2}$. Comment (G.ö.): surprisingly great age led to more comprehensive study of sediment obtained after melting procedure. Microscopic grains of pure graphite were found and assumed to originate from carboniferous Cambro-Silurian rocks in vicinity. Tentative correction for opaque and "dead" graphite grains brings age forward to 13,330 B.P. However, obviously other carbon-bearing ("semimetamorphosed") rock particles were present in sample, for which a reliable correction will be very difficult.

\section{T-347. Tarfala glacier, Pit D}

$5000 \pm 600$ 3050 B.c.

Sample coll. similar to T-345A. Contamination of old carbon as in T-346B. Comment (G.ö.): correction for graphite gave age 3000 B.P., a 
maximum age for ridge, as no correction was made for other carbonbearing material that may be present.

\section{T-348. Tarfala glacier, Pit E}

$9660 \pm 210$

Ice sample from outermost ridge in end moraine system (see also T-346). Comment (G.ö.): correction for graphite grains gave age 7260 B.P., but no correction was possible for other carbonaceous material (St-1535 to 1537, Radiocarbon, 1965, v. 7, p. 289).

\section{Finland}

\section{Mustajärvi series, Finnish Lappland}

Samples coll. with piston drill from bottom of Lake Mustajärvi, Kittilä (25 $15^{\prime} \mathrm{E}$ Long, $67^{\circ} 40^{\prime} \mathrm{N}$ Lat), Finnish Lappland. Lake is at +193 m, at depth $2 \mathrm{~m}$, where samples were coll. Coll. and subm. 1963 by Martti Salmi, Inst. of Geol., Turku Univ. $\mathrm{C}^{14}$ dates were only based on organic fraction of samples. Comment (M.S.): profile of Lake Mustajärvi contains much Pediastrum and many fresh-water mollusc shells (Salmi, 1965).

\section{T-407. Mustajärvi 1}

$12,690 \pm 190$

Comelow level, above silt. Comment (M.S.): according to pollen analysis, horizon represents beginning of Betula-maximum: 74\% Betula, 25\% Pinus, $1 \%$ Picea. Vigorous spread of Pediastrum began at this level. Sample contains many dark plant remains.

\section{T.408. Mustajärvi 2}

$$
10,070 \pm 150
$$

Pediastrum-lime ooze with fresh-water mollusc shells 5.13 to $5.22 \mathrm{~m}$ below bottom surface. Comment (M.S.): according to pollen analysis, horizon represents latter part of Betula-maximum: 91\% Betula, 9\% Pinus. Pcdiastrum decreases at this level.

\section{T-409. Mustajärvi 3}

$$
10,010 \pm 140
$$
8060 B.c.

Pediastrum-lime ooze 4.32 to $4.40 \mathrm{~m}$ below bottom surface. Comment (M.S.): according to pollen analysis, from upper part of Betula-maximum: 2\% Alnus, $55 \%$ Betula, $42 \%$ Pinus. Sediment is striped.

\section{Siikaneva series, W Finland}

Samples coll. with piston drill from bog Siikaneva, Ruovesi $\left(61^{\circ} 50^{\prime}\right.$ $\mathrm{N}$ Lat, $24^{\circ} 10^{\prime}$ E Long), W Finland. Bog is at $+170 \mathrm{~m}$. Coll. 1962 and subm. 1964 by Martti Salmi. $\mathrm{C}^{14}$ dates were only based on organic fraction of samples.

\section{T-432. Siikaneva 1}

$9100 \pm 100$

Fine and coarse detritus ooze 7.95 to $8.05 \mathrm{~m}$ below bog surface. 
Comment (M.S.): according to pollen analysis, horizon represents latter part of Pre-Boreal Betula-maximum.

T-433. Siikaneva 2

$8400 \pm 130$

6450 B.c.

Peat (Sphagnum-Carex) 7.45 to $7.55 \mathrm{~m}$ below bog surface. Comment (M.S.): according to pollen analysis, horizon represents beginning of Alnus curve and Boreal Pinus period.

T-434. Siikaneva 3

$4410 \pm 90$

2460 B.c.

Peat (Sphagnum-Carex) 3.95 to $4.05 \mathrm{~m}$ below bog surface. Comment (M.S.): according to pollen analysis, vigorous spread of Picea began in area at that time and horizon represents Sub-Boreal period.

\section{Sottujoki palsa series, N Finland}

Samples from various profiles in bog at +391 to $394 \mathrm{~m}$ in Sottujoki palsa area, Enontekiö (68 $36^{\prime} \mathrm{N}$ Lat, $21^{\circ} 52^{\prime} \mathrm{E}$ Long), N Finland. Coll. 1967 and subm. 1968 by Martti Salmi. Comment (M.S.): Profiles 3 and 4 are taken from the palsa, Profile 9 from peat bog adjacent to Sottujoki palsa (Salmi, 1968).

T-699. Profile 4, 11/MS

$5170 \pm 70$

with spade at depth 0.55 to $0.60 \mathrm{~m}$, above permafrost. Pollen analysis (M.S.): Pinus maximum.

\section{T-700. Profile 4, $12 / \mathrm{MS}$}

$6010 \pm 120$

Peat (Bryales-wood) coll. with borer at depth 1.0 to $1.05 \mathrm{~m}$, above silt. Pollen analysis (M.S.): on limit between Betula and Pinus maximum.

\section{T-701. Profile 3, 13/MS}

$7020 \pm 100$

Peat (Sphagnum-Carex) coll. with spade at depth 0.55 to $0.6 \mathrm{~m}$, above permafrost. Pollen analysis (M.S.): from middle of Pinus maximum with $55 \%$ Pinus, $44 \%$ Betula, $1 \%$ Alnus.

\section{T-708. Profile 3, 22/MS}

$8480 \pm 110$

6530 B.C.

Peat (Carex-Sphagnum) coll. with borer at depth 1.7 to $1.8 \mathrm{~m}$. Pollen analysis (M.S.): from middle of Betula maximum.

\section{T-702. Profile 3, 14/MS}

$8490 \pm 110$

Peat (Bryales-Carex) coll. with borer at depth 2.7 to $2.8 \mathrm{~m}$, above silt. Pollen analysis (M.S.): from lowest part of Betula maximum.

T-707. Profile 9, 18/MS

$5030 \pm 90$

3080 B.C.

Peat (Carex-Sphagnum) coll. with spade at depth 0.45 to $0.55 \mathrm{~m}$. Pollen analysis (M.S.): from upper part of Pinus maximum. 
T-706. Profile 9, 17/MS

$5630 \pm 100$

Peat (Carex-Sphagnum) coll. with borer at depth 0.95 to $1.05 \mathrm{~m}$. Pollen analysis (M.S.): from middle of Pinus maximum.

\section{T-705. Profile 9, 16/MS}

$7950 \pm 110$

Peat (wood-Sphagnum) coll. with borer at depth 1.75 to $1.85 \mathrm{~m}$. Pollen analysis (M.S.): at limit between Betula and Pinus maximum.

\section{T-703. Profile 9, 15/MS}

$8000 \pm 120$

Sandy gyttja coll. with borer at depth 1.95 to $2.0 \mathrm{~m}$. Pollen analysis (M.S.): from Betula maximum.

\section{T.709. Pinus, 25/MS}

$4930 \pm 110$

2980 B.c.

Wood (Pinus) from Sottujoki palsa with spade at depth 0.95 to $1.0 \mathrm{~m}$, in contact between peat and frozen mineral soil. Pinus trunk was ca. $4 \mathrm{~m}$ long. Comment (M.S.): Sottujoki palsa situated $21 \mathrm{~km} \mathrm{~N}$ of present Pinus forest limit. According to pollen analysis, Pinus horizon represents Pinus maximum.

\section{Canada}

\section{L'Anse aux Meadows series, Newfoundland}

Peat and gyttja from bogs and tarns at and in surroundings of Norse settlement site, L'Anse aux Meadows, ( $51^{\circ} 34^{\prime} \mathrm{N}$ Lat, $55^{\circ} 35 \mathrm{~W}$ Long), Newfoundland, Canada. All samples except T-530 and T-531 coll. with Hiller borer. T-530 and T-531 coll. by knife from peat wall of ruins. Coll. 1962 by Kari Henningsmoen, Univ. of Oslo, during one of L'Anse aux Meadows expeditions by Helge Ingstad (see archaeologic section, this date list). Subm. 1965 by K. Henningsmoen. Comment (K.H.): 1) vegetation seems to have been very similar ca. $1000 \mathrm{yr}$ ago as it is today. Eventual changes in climatic conditions have been too small to be recognizable in pollen diagrams. Vegetational changes shown by diagrams seem to be a) different in age from Norse settlement, and/or b) due to local ecologic development of sampling sites. 2) European weeds are, so far, found only in a few very young samples, reflecting influence of more recent invasion of European man. 3) Sea level changes during last $7500 \mathrm{yr}$ amount to relative rise of land of ca. $31 \mathrm{~m}$. Sea level may have been 0.50 to $0.75 \mathrm{~m}$ higher $1000 \mathrm{yr}$ ago than it is today. Additional sample series have been coll. during summer 1968, to control and supply results so far obtained.

\section{T-500. Pond at L'Anse aux Meadows}

Gyttja from depth $1.75 \mathrm{~m}$ below lake surface, at contact between inorganic and organic deposits. Sample from layers 0 to $0.10 \mathrm{~m}$ above level of contact. 


\section{T-501. Tarn $W$ of Saddle Hill Pond}

$\left(51^{\circ} 35^{\prime} \mathrm{N}\right.$ Lat, $55^{\circ} 32^{\prime} \mathrm{W}$ Long), ca. + $31 \mathrm{~m}$. Gyttja from depth $3.77 \mathrm{~m}$ below lake surface, at contact between inorganic and organic deposits. Sample from layers 0 to $0.10 \mathrm{~m}$ above level of contact.

\section{T-502. Pond between Ship Cove and Raleigh}

$6420 \pm 130$

( $51^{\circ} 34^{\prime} \mathrm{N} \mathrm{Lat}, 55^{\circ} 40^{\prime} \mathrm{W}$ Long), ca. $+52 \mathrm{~m}$. Gyttja from depth 2.65 $\mathrm{m}$ below lake surface, at contact between inorganic and organic deposits. Sample from layers 0 to $0.10 \mathrm{~m}$ above level of contact.

\section{T-503. Tarn at Straitsview}

$1960 \pm 90$

$\left(51^{\circ} 36^{\prime} \mathrm{N}\right.$ Lat, $55^{\circ} 31^{\prime} \mathrm{W}$ Long), at $+1.4 \mathrm{~m}$. Gyttja from depth $0.68 \mathrm{~m}$ below lake surface, at contact between inorganic and organic deposits. Sample from layers 0 to $0.10 \mathrm{~m}$ above level of contact.

\section{Turf walls, L'Anse aux Meadows}

Turf samples from 2 houses, A and F, in dig. Walls had collapsed and shrunk vertically together, and were completely overgrown by younger turf.

\section{T-530. Turf wall, House A}

$$
950 \pm 90
$$

T-531. Turf wall, House $F$

$$
\begin{gathered}
\text { A.D. } 1000 \\
\mathbf{9 5 0} \pm \mathbf{5 0} \\
\text { A.D. } 1000
\end{gathered}
$$

Comment (K.H.): younger turf may have contaminated older walls and consequently given samples somewhat low age, or, more likely, walls were built up of mats of living turf, so that age is close to time when houses were built.

\section{T-532. Skin Pond}

$6610 \pm 150$ 4660 в.c.

$\left(51^{\circ} 33^{\prime} \mathrm{N}\right.$ Lat, $55^{\circ} 35^{\prime} \mathrm{W}$ Long), ca. + $20 \mathrm{~m}$. Gyttja from depth 1.80 $\mathrm{m}$ below lake surface, at contact between inorganic and organic deposits. Sample from layers 0 to $0.10 \mathrm{~m}$ above contact.

T-533. L'Anse aux Meadows, peat from dig area

$$
1480 \pm 100
$$

$\left(51^{\circ} 34^{\prime} \mathrm{N}\right.$ Lat, $55^{\circ} 35^{\prime} \mathrm{W}$ Long), ca. $30 \mathrm{~m}$ from House F. Peat cover of varying thickness extends over whole area around dig. Sample from thickest part of peat, viz. $0.52 \mathrm{~m}$, and consists of bottom peat layers, 0.42 to $0.52 \mathrm{~m}$ below peat surface.

\section{ARCHAEOLOGIC SAMPLES}

\section{A. Canada}

\section{Norse settlement at L'Anse aux Meadows, Newfoundland series}

A Norse settlement site was discovered in Newfoundland in 1960 by Helge Ingstad, who previously set forth theory that Vinland mentioned 
in Icelandic sagas and discovered by Norsemen ca. 1000 A.D., must be in Newfoundland (Ingstad, 1959, 1966). He made 7 archaeologic expeditions to the site (1961 to 1968), during which Anne Stine Ingstad was in charge of archaeologic work. Comment (H.I.): L'Anse aux Meadows $\left(51^{\circ}\right.$ $34^{\prime} \mathrm{N}$ Lat, $55^{\circ} 35^{\prime} \mathrm{W}$ Long) is at $\mathrm{N}$ tip of Newfoundland somewhat $\mathrm{W}$ of Cape Bauld. All sites mentioned below are located on old beach terrace ca. $+4 \mathrm{~m}$, and near Épaves Bay. Sandbed is overlain with humus mixed with sand and covered by turf. Eight house sites were excavated, all of which have walls of turf, except for two dug into terrace; also a kiln, 2 large outdoors cooking pits, and sites of 4 boat sheds in a row. According to archaeologic assessment, house sites are Norse and from 1000 to 1100 A.D.

Nearby Épaves Bay is typical bay where driftwood would accumulate along beach in great quantities. In the rather cool climate of $\mathrm{N} N$ Newfoundland driftwood would be preserved for considerable time. In this way some radiocarbon measurements might indicate older dates than the time when the driftwood was coll.

Laboratory Comment (R.N.): the 16 radiocarbon dates (Turf walls, T-530 and T-531 included, see Fig. 1) have mean value of $910 \pm 20 \mathrm{yr}$ A.D., where only statistical errors are suggested in calculation. According to Ingstad, storage time of driftwood may have influenced some dates. Ages of samples coincide with period when $\mathrm{C}^{14}$ ages are somewhat greater than true ages (Willis et al., 1960; Suess, 1965; Kigoshi, 1965; Dyck, 1965). Latter error alone could have made all dates $100 \mathrm{yr}$ too old. Mean $\mathrm{C}^{14}$ age ca. $1000 \mathrm{yr}$ A.D. is in reasonable agreement with the age expected by Ingstad.

\section{T-310. House Site A}

$1310 \pm 130$

Scattered charcoal from test excavation $0.25 \mathrm{~m}$ below turf surface in sand and above floor of site. Area had been washed over by R. Black Duck Brook. Coll. 1961 by A. S. Ingstad, cooperating with Univ. Mus. of Natl. Antiquities, Oslo; subm. by S. Richter, Norsk Polarinst., Oslo. Comment: this is an early test measurement and deals with scattered charcoal from middle part of cultural layer. In 1967 and 1968 excavation was continued down to the floor and extended toward river. A house site of Norse type, $24 \mathrm{~m}$ long and $4 \mathrm{~m}$ wide (inside measurement) was uncovered. Walls outside are of turf and very distinct. Among finds: some very rusted nails, fragments of iron, lumps of slag, and a ringheaded bronze pin of a type commonly used during Viking period. Radiocarbon measurement from turf wall (T-530) gave age A.D. $1000 \pm 90$.

\section{T-306. House Site B}

$1210 \pm 110$

Charcoal from cooking pit, from depth $0.55 \mathrm{~m}$ below turf surface in $4.75 \times 3.40 \mathrm{~m}$ house site with turf walls. Coll. 1961 by A. S. Ingstad; subm. by S. Richter. Comment: a piece of slag was found in cooking pit. Of particular interest is stone made Norse type ember pit. 


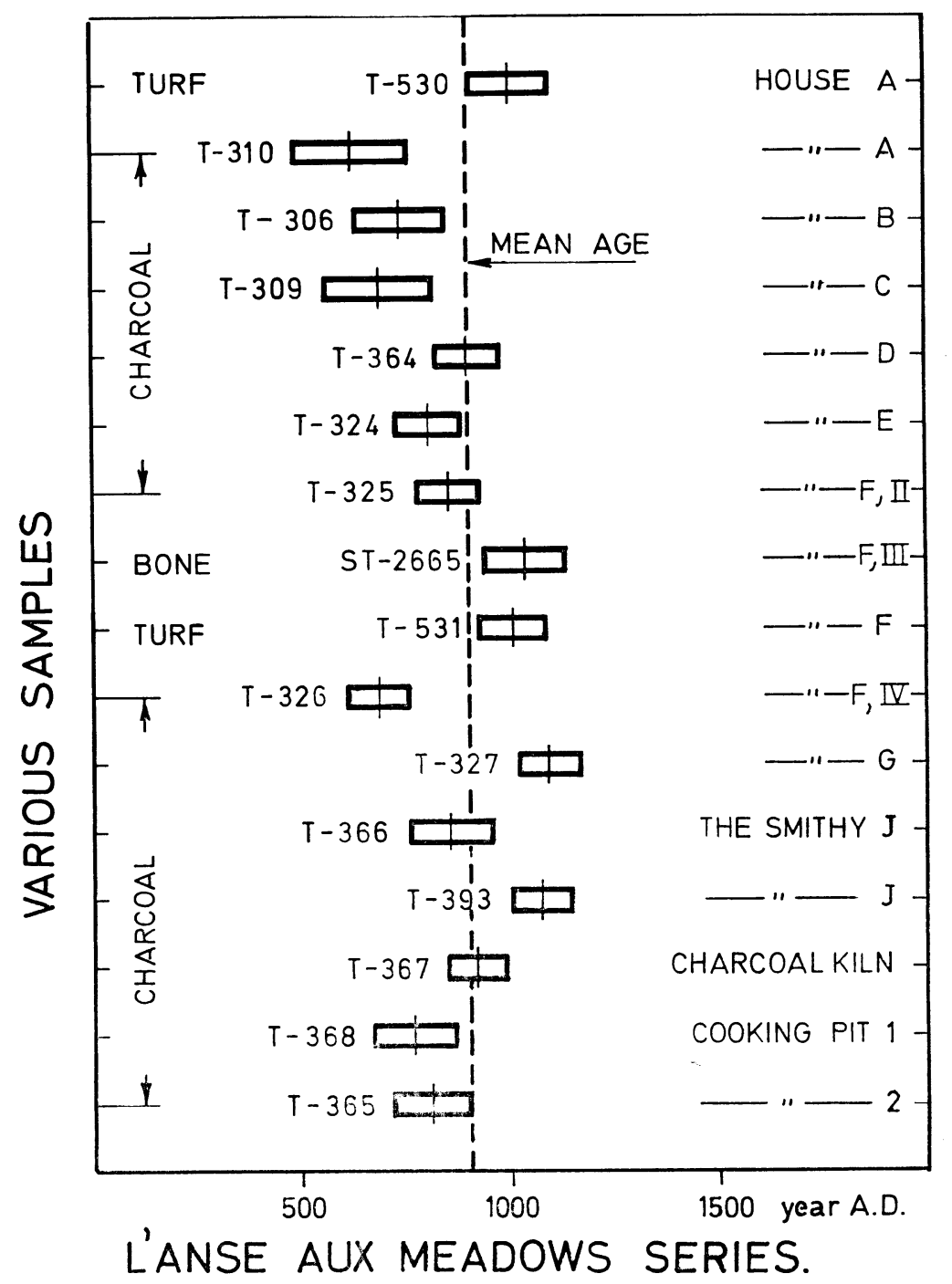

Fig. 1.

\section{T-309. House Site C}

$$
1240 \pm 130
$$

Charcoal from scorched patch at floor level, from depth $0.20 \mathrm{~m}$ below turf surface in $2.75 \times 2.75 \mathrm{~m}$ house site with turf walls. Coll. 1961 by A. S. Ingsted; subm. by S. Richter. Comment: 2 pieces of slag were found in house site, and a very rusted nail was found in a small midden outside door. 


\section{T.364. House Site D}

$1050 \pm 70$

Charcoal from fireplace $0.40 \mathrm{~m}$ below turf surface in $10 \times 5 \mathrm{~m} \mathrm{NE}$ room of house site. Coll. 1962 by Rolf Petré, Univ. of Lund; subm. by H. Ingstad. Comment: house-site, which is Norse type, consists of 2 lengthwise rooms with inside area of $18.3 \times 5.0 \mathrm{~m}$, and small projecting room to N. In fireplace where charcoal was coll., a fragment of copper with simple ornaments was found. Other finds: a bone needle and a stonemade ember pit of Norse type beside rusted nails and slag.

\section{T.324. House Site E}

$1130 \pm 70$

Charcoal from fireplace from depth $0.40 \mathrm{~m}$ below turf surface in $3.75 \times 3.30 \mathrm{~m}$ house site with turf walls. Coll. 1961 by A. S. Ingstad; subm. by $\mathrm{H}$. Ingstad.

\section{T-325. House Site F, Room II}

$1080 \pm 70$

Charcoal from $1.90 \mathrm{~m}$ long fireplace in Rm. II, $0.60 \mathrm{~m}$ deep in fireplace, which is Norse type and situated in central largest room. Coll. 1961 by A. S. Ingstad; subm. by H. Ingstad. Comment: House Site F has inside area of $14 \times 21 \mathrm{~m}$, containing 6 rooms with turf walls. Finds were very rusted nails, fragment of iron and slag, a stone lamp, and a spindle whorl of Norse-type soapstone. Radiocarbon measurement from turf wall (T-531) gave age of $1000 \pm 50 \mathrm{yr}$ A.D.

\section{T-326. House Site F, Room IV}

$$
1250 \pm 70
$$

Charcoal from stone fireplace in $\mathrm{Rm}$. IV, $0.30 \mathrm{~m}$ deep in NE room, $3.0 \times 3.5 \mathrm{~m}$. Coll. 1962 by A. S. Ingstad; subm. by H. Ingstad (see comment for $\mathrm{T}-325)$.

\section{St-2665. House Site F, Room III}

$925 \pm 100$

Fragment of whale bone from fireplace in House Site F, Rm. III. Coll. 1967 by A. S. Ingstad and M. Stenberger; subm. by M. Stenberger, Univ. of Uppsala. Comment: (See comment for T-325). $\mathrm{C}^{14}$ dated 1967 by L. Engstrand, Radioactive Dating Lab., Stockholm.

\section{T-327. House Site G}

$870 \pm 70$

\section{A.D. 1080}

Charcoal from fireplace $0.50 \mathrm{~m}$ deep in $3.0 \times 2.75 \mathrm{~m}$ house site dug into flank of terrace. Coll. 1961 by A. S. Ingstad; subm. by H. Ingstad. Comment: a number of firecracked stones and other features might indicate that this house site was vapor bath as known from Norse area. Finds: 2 nails and fragment of iron.

\section{The Smithy J}

Charcoal from forge $0.30 \mathrm{~m}$ below peat surface in $3.75 \times 2.75 \mathrm{~m}$ house site, dug into flank of terrace near Black Duck Brook. Coll. 1962 by K. Eldjarn and G. Gestsson, Natl. Mus. of Iceland; subm. by H. Ingstad. 
T-366. The Smithy J

Inside 2 small stones.

\section{T-393. The Smithy J}

In front of the 2 small stones. Comment: flat, partly broken stone, which must have been anvil, was found in central part of floor. Many hundred pieces of slag, some bog iron and small fragments of iron were found on floor, which was partly black from soot and charcoal.

\section{T-367. Charcoal kiln}

$1130 \pm 70$

Charcoal from bottom of charcoal layer in outdoor pit dug down into terrace ca. $7 \mathrm{~m} \mathrm{SW}$ of smithy; $0.75 \mathrm{~m}$ deep, surface and bottom area $2.0 \times 0.8 \mathrm{~m}$ and $1.5 \times 0.8 \mathrm{~m}$, respectively. Charcoal layer at bottom is ca. $0.20 \mathrm{~m}$ thick. Much charcoal also appears above this layer more or less mixed with sand. Coll. 1962 by K. Eldjarn and G. Gestsson; subm. by H. Ingstad. Comment: charcoal was probably produced for use in smithy in this pit. Judging from slag found in smithy and several house sites and from bog iron found in turf nearby, charcoal might also have been used for melting bog iron.

\section{T-368. Cooking Pit 1, near bridge}

$1170 \pm 90$

Charcoal from bottom of pit ca. $10 \mathrm{~m} \mathrm{~W}$ of bridge across R. Black Duck Brook. Pit is $0.70 \mathrm{~m}$ deep, with surface and bottom areas $1.10 \times$ $2.30 \mathrm{~m}$ and $1.10 \times 1.60 \mathrm{~m}$, respectively, dug into beach terrace, containing 0.04 to $0.15 \mathrm{~m}$ thick layer of charcoal in bottom, continuing up sides and covered by reddish sand. Layer of firecracked strandstones the size of a fist were on top of and partly in the sand. Coll. 1962 by G. Gestsson and K. Eldjarn; subm. by H. Ingstad.

\section{T-365. Cooking Pit 2, near House Site F}

$1140 \pm 90$

Charcoal from bottom of pit ca. $10 \mathrm{~m} \mathrm{NW}$ of House Site F, $0.70 \mathrm{~m}$ deep, dug in beach terrace, with turf surface ca. $3 \mathrm{~m}$ diam. and bottom diam. $2.30 \mathrm{~m}$. Charcoal layer is $0.05 \mathrm{~m}$ thick, and wall layer has maximum thickness $0.20 \mathrm{~m}$. Considerable number of firecracked strandstones the size of a fist were found in layer of sand mixed with soot. Coll. 1962 by R. Petré; subm. by H. Ingstad. Comment: fragment of iron found at bottom, and some stone artifacts from natives were found at other places in and outside pit.

\section{B. Marquesas Isles}

\section{Tohua series, Marquesas Isles}

Charcoal samples from ceremonial place (Tohua) in Puamau valley, Hiva Oa, Marquesas Isles ( $9^{\circ} 45^{\prime} \mathrm{N}$ Lat, $139^{\circ} 00^{\prime} \mathrm{E}$ Long), French Polynesia. Coll. 1963 and subm. 1968 by A. Skjölsvold, Univ. Oldsaksamling, Oslo. Comment (A.S.): central part of this Tohua consists of platform, 
showing 2 building steps. In lst step, platform is built as low, earth bank, and in 2nd step it is built as rectangular stone wall, built on top of earth bank. Some erected slaks were found, which possibly mark extension of placa (dancing place) in connection with youngest period of the Tohua.

This Tohua was excavated as part of survey carried out by Norwegian archaeologic expedition in 1963 to 1964, organized by Thor Heyerdahl and conducted by A. Skjölsvold. Expedition was financed by Kon Tiki Mus., Oslo.

\section{T-717. Puamau (XX)}

A.D. 1190

$760 \pm 70$

Coll. from thin charcoal layer at bottom of earth bank. Comment (A.S.): date should indicate beginning of work on 1st building period.

T.719. Puamau (H.H.H.)

$560 \pm 70$

Coll. at depth $0.20 \mathrm{~m}$ in hole, which belongs to pole of supposed wood construction belonging to oldest part of platform.

T-720. Puamau (r)

A.D. 1550

$$
400 \pm 70
$$

Coll. in stone packing belonging to youngest part of platform.

\section{T-721. Puamau (L.L.L.)}

A.D. 1550

$400 \pm 60$

Charcoal coll. from thin charcoal layer on top of earth bank forming lst building step. Sample should date beginning of construction of stone platform, which comprises last building step.

T.718. Puamau (M.M.M.)

$$
290 \pm 70
$$

Charcoal from fire pit $(u m u)$ under one of edging stones marking enclosure of ceremonial place (dancing place) connected with the Tohua. Comment (A.S.): sample should outdate construction of the "fence."

\section{Stone age settlement}

$$
\text { C. Norway }
$$

\section{Radöy series, Hordaland}

Charcoal from habitation layer rich in artifacts in settlement site in Straume, Radöy, (60 $40^{\circ}$ N Lat, $4^{\circ} 43^{\prime}$ E Long), Hordaland, Norway. Site covered area of ca. $300 \mathrm{~m}^{2}$, and habitation layer had maximum depth $1.5 \mathrm{~m}$. Sample T-430 coll. above shore gravel at bottom of layer (Sq. M.9, Layer VIII). Sample T-431 coll. $0.10 \mathrm{~m}$ above rock bottom (Sq. M.9, Layer VIII). Coll. and subm. 1963 by E. Bakka, Historical Mus., Univ. of Bergen.

\section{T-430. 0.92 to $0.95 \mathrm{~m}$ depth}




\section{T-431. 0.80 to $0.85 \mathrm{~m}$ depth}

Comment (E.B.): archaeologic date of all undisturbed cultural deposits of site is middle Neolithic period (ca. 1800 to 2500 B.c.); samples belong to earlier cultural phase of site, but not necessarily from beginning of middle Neolithic period. Estimated archaeologic date of samples is 2000 to 23,000 B.C., or ca. $1000 \mathrm{yr}$ later than radiocarbon dates (Bakka, 1964).

\section{Laerdal series, Sogn- og Fjordane}

Charcoal from settlement sites in Lærdal. Sample T-671 coll. from alt $1420 \mathrm{~m}\left(61^{\circ} 5^{\prime} \mathrm{N}\right.$ Lat, $\left.8^{\circ} 14^{\prime} \mathrm{E} \mathrm{Long}\right)$, and the other from alt $1120 \mathrm{~m}$ $\left(61^{\circ} 1^{\prime} \mathrm{N}\right.$ Lat, $8^{\circ} 7^{\prime} \mathrm{E}$ Long), Sogn- og Fjordane, Norway. Coll. and subm. 1967 by A. B. Johansen, Historical Mus., Univ. of Bergen.

T-664. Osen II (E9)

Fireplace $0.30 \mathrm{~m}$ deep.

T-665. Osen II (F8)

$0.40 \mathrm{~m}$ deep.

T-666. Osen II (F11)

Fireplace $0.30 \mathrm{~m}$ deep.

T-667. Jukleåni (N13)

$0.30 \mathrm{~m}$ deep.

T-668. Jukleåni (M12)

Fireplace 0.40 to $0.50 \mathrm{~m}$ deep.

T-669. Jukleåni (T15)

$0.20 \mathrm{~m}$ deep.

T-670. Mörkedöla I (I17)

Ca. $0.10 \mathrm{~m}$ deep.

\section{T-671. Sulemarki VII (K16-17)}

$0.45 \mathrm{~m}$ deep.
$8290 \pm 120$

6340 B.C.

$7500 \pm 110$

5500 в.C.

$7120 \pm 120$ 5170 в.C.

$7530 \pm 100$

5580 в.C.

$7410 \pm 100$

5460 в.C.

$7180 \pm 110$ 5130 B.c.

$4830 \pm 160$ 2888 B.C.

$7910 \pm 120$ 5970 в.C.

Comment (A.B.J.): findings in Stone age settlements in $\mathrm{mts}$. are usually located in region between peat and gravel at maximum depth $0.10 \mathrm{~m}$, (see Sample T-670). Other samples with appreciably higher age were found in sterile gravel at depth ca. $0.30 \mathrm{~m}$. Most reasonable explanation is that settlement occurred in 2 periods with such a great time interval that gravel sedimentation from sand deposit took place. According to our knowledge, about retreat of ice sheet (Hafsten, 1965), earliest settle- 
ment in $\mathrm{mt}$. took place at edge of retreating ice sheet. Dates above might give decisive contribution to discussion of character of oldest mt. settlements (Hagen, 1960-1961, p. 141; Odner, 1965, p. 237).

\section{Karmöy series, Rogaland}

Samples from several dwelling places at $+10 \mathrm{~m}$ in Håvik, Avaldsnes, Karmöy, (59 $20^{\prime} \mathrm{N}$ Lat, $5^{\circ} 25^{\prime} \mathrm{E}$ Long) Rogaland, Norway. Both material and artifacts vary from one place to the other. Archaeologic date (O.M.): younger Stone age. Coll. 1963; subm. 1964 by O. Möllerop, Stavanger Mus., Stavanger.

T.480. Håvik (K-C-1)

Coll. within area of $1 \mathrm{~m}^{2}$.

T-481. Håvik (M-Grop I)

Coll. in charcoal pit.

T-482. Håvik ( N-11 h)

Coll. in cultural layer within $1 \mathrm{~m}^{2}$.

T-483. Håvik (T-10 B)

Coll. in cultural layer within $1 \mathrm{~m}^{2}$.

T-484. Håvik (R-4a)

Coll. in cultural layer within $1 \mathrm{~m}^{2}$.
$4040 \pm 80$

2090 B.C.

$3080 \pm 100$

1130 B.C.

$5490 \pm 130$

3530 в.c.

$4970 \pm 130$

3020 B.c.

$3330 \pm 80$

1380 в.c.

\section{Lysheiane series, Rogaland}

Charcoal from several dwelling places in Lysheiane, Rogaland. Archaeologic date: younger Stone age. Samples were mainly coll. 1962; subm. 1964 by O. Möllerop. Comment (I.M.): material from these dwelling places is not fully worked out but seems to fit nicely with material from other mt. dwelling places in S Norway. Arrowhead types, scrapers as well as material (flint) seems to indicate that dwelling places were inhabited by people coming up from sea dwellings during seasons.

\section{T.450. Nilsebu (IV B-2)}

$4330 \pm 120$

Charcoal at outlet of Nilsebuvann, (59 $19^{\circ} \mathrm{N}$ Lat, $4^{\circ} 6^{\prime} \mathrm{E}$ Long), Rogaland, Norway. Found in charcoal layer $0.20 \mathrm{~m}$ below peat.

\section{T-452. Storhidler}

$7130 \pm 140$

Charcoal at Storhidlervann, Årdal $\left(59^{\circ} 12^{\prime} \mathrm{N}\right.$ Lat, $4^{\circ} 7^{\prime} \mathrm{E}$ Long), Norway, from 0.20 to $0.35 \mathrm{~m}$ thick cultural layer with flint artifacts. Coll. 1962 by P. Rolfsen. Comment (O.M.): only small part of dwelling place is excavated, and younger artifacts than $\mathrm{C}^{14}$ age were also found. 


\section{T-445. Fistöylvatn I, Aust-Agder}

Charcoal from Stone age settlement at $+600 \mathrm{~m}$ in Finndalen, Valle, $\left(59^{\circ} 10^{\prime} \mathrm{N}\right.$ Lat, $7^{\circ} 40^{\prime} \mathrm{E}$ Long), Aust-Agder, Norway. Finds located in sandy ground just under peat. Sample coll. in carbon concentration found directly on subsoil. Archaeologic date: 5000 to 2000 в.c. Coll. 1961 by A. E. Christensen; subm. 1964 by I. Martens. Comment (I.M.): finds belong to same main group (Fosna culture) as those from Finseöya I A, but differ from them in several respects. They are of Mesolithic character, but there is still disagreement between archaeologists on date of earliest phase (Odner, 1965).

\section{T-446. Digernes I, Buskerud}

$7380 \pm 120$

Charcoal from Stone age settlement, at $+985 \mathrm{~m}$ at Ustevatn, Hol, $\left(60^{\circ} 30^{\prime} \mathrm{N}\right.$ Lat, $8^{\circ} 0^{\prime} \mathrm{E}$ Long), Buskerud, Norway. Site was covered with thin layer of peat. Sample from pit 0.50 to $0.60 \mathrm{~m}$ deep. Archaeologic date: 5000 to 2000 в.c. Coll. 1960 by Th.S. Eikholm; subm. 1964 by I. Martens. Comment (I.M.): finds cannot be connected with any wellknown Norwegian Stone age cultures, but are of Mesolithic character. Another sample from same site dated in Copenhagen at $5460 \pm 130$ B.c. Agreement between 2 dates is extremely good.

\section{T-223. Finseöya (IA), Buskerud}

$7650 \pm 200$ 5700 B.c.

Charcoal from Stone age settlement at $+1215 \mathrm{~m}$ at Finsevatn, Hol, $\left(60^{\circ} 35^{\prime} \mathrm{N}\right.$ Lat, $7^{\circ} 30^{\prime} \mathrm{E}$ Long), Buskerud, Norway. Thin peat layer covered site, mainly containing quartzite artifacts. Sample from fire pit 0.30 to $0.40 \mathrm{~m}$ deep. Coll. 1961 by Th.S. Eikholm; subm. by I. Martens. Comment (I.M.): finds belong to Fosna group (see comments to T-445). Several dates of related finds from Lærdalsvassdraget come very close to this one (Hagen, 1960).

\section{T-696. Vestredalshelleren, Buskerud}

$3840 \pm 90$ 1890 B.C.

Charcoal from rock shelter at $+1140 \mathrm{~m}, 0.50 \mathrm{~m}$ deep, at Vestredalstjern, Hol, $\left(60^{\circ} 45^{\prime} \mathrm{N}\right.$ Lat, $7^{\circ} 40^{\prime} \mathrm{E}$ Long), Buskerud, Norway. Artifacts belong to late Stone age and early Metal age. Coll. 1967 by A. Stalsberg; subm. by I. Martens. (See comment to T-697, this date list).

\section{Gråmyra series, Romsdal}

Charcoal from 2 different fire pits in older Stone age site in Gråmyra, Otteröy, (62 $41^{\prime} \mathrm{N}$ Lat, $6^{\circ} 39^{\prime} \mathrm{E}$ Long), Möre og Romsdal, Norway. Coll. and subm. 1963 by Kr. R. Möllenhus, Videnskapsselskapets Oldsaksamling, Trondheim.

\section{T-422. Gråmyra I}




\section{T-423. Gråmyra II}

Comment (Kr.R.M.): fire pits were on Tapes terrace (b-line). Poor inventory material from site had Mesolithic character. A slate arrow point was single artifact of late Stone age type, found on same level as fire pits. Archaeologic material appears to represent 2 chronologically different settlements. If so, fire pits must evidently belong to later settlement, that is, to same period as slate point.

Trollvika series, Romsdal

Charcoal from Stone age site in Trollvika, Otteroy, $\left(62^{\circ} 40^{\prime} \mathrm{N}\right.$ Lat, $6^{\circ} 40^{\prime}$ E Long) Möre og Romsdal, Norway. Sample coll. just below cultural layer containing artifacts.

\section{T-555. Trollvika I}

$2340 \pm 90$

390 B.C.

T-556. Trollvika II

$2590 \pm 100$

Comment (Kr.R.M.): site may be divided into 3 separate locations. Lowest location with slate objects is beneath Tapes terrace (b-line). Cultural layer on terrace contained stone axes of late Nöstvet type with partly ground surface. Location higher than terrace showed materials of mesolithic character. Dated charcoal from cultural layer indicate that late Nöstvet axe and use of stone artifacts, in general, continued into Metal ages.

\section{Ålbusetra series, Sör-Tröndelag}

Charcoal from settlement site at Ålbusetra, Oppdal, $\left(62^{\circ} 3^{\prime} \mathrm{N}\right.$ Lat, $10^{\circ} 3^{\prime}$ E Long), Sör-Tröndelag, Norway. Charcoal was found among wastes and flint artifacts. Coll. 1963 by H. Aalbu, and subm. 1964 by Marstrander, Univ. Oldsaksamling.

T-442. Ålbusetra, A

$6100 \pm 120$

From fireplace.

\section{T-443. Ålbusetra, B}

4150 B.C.

Surface sample.

Comment (S.M.): artifacts of flint and quartz found 1948 to 1949 in moraines in mt. regions between Oppdal and Kvikne at +960 to $990 \mathrm{~m}$. Flint must originate from coastal deposits; types and technique of artifacts indicate connections with finds of Fosna type from dwelling places in coastal area. It is 1st time material of Fosna character has been dated in Tröndelag region.

\section{Iron age settlement}

\section{Naerbö series, Rogaland}

Samples from dwelling place Klauhauane on farm ödemotland, $\left(58^{\circ} 39^{\prime} \mathrm{N}\right.$ Lat, $5^{\circ} 7^{\prime} \mathrm{E}$ Long) Rogaland, Norway. It contained ca. 20 
houses arranged in circle around open place where roof of a square house was found. This house had palisade-like walls of timber. No fire pits were found in site, but several pits were located outside and at same level. Coll. 1960 and subm. 1961 by O. Möllerop. Comment (O.M.): square house is either contemporary with, or younger than fire pits. At higher level above house, potsherds older than $\mathrm{C}^{14}$ age were found. House must, therefore, either have been set up by digging through older cultural layers or charcoal from walls must have been mixed with younger material.

T-328. Klauhauane, central house Charcoal from wall.

T-420. Klauhauane, Pit II

Charcoal from fire pit.

T-421. Klauhauane, Pit III

Charcoal from fire pit.
$1590 \pm 100$ A.D. 360

$$
1920 \pm 100
$$

A.D. 30

$2080 \pm 100$ 130 B.C.

\section{Risavika series, Rogaland}

Charcoal from dwelling place Risavika on Tjoraneset, Sola, $\left(58^{\circ}\right.$ $55^{\prime} \mathrm{N}$ Lat, $5^{\circ} 8^{\prime}$ E Long), Rogaland, Norway. Archaeologic date: probably younger Iron age. Coll. 1964 to 1965 by several archaeologists at Stavanger Mus.; subm. 1966 by O. Möllerop.

T-557. Risavika, Site 13

$$
1260 \pm 80
$$

\section{A.D. 690}

Charcoal from fireplace in site of farm. Fireplace was situated at long-wall. Archaeologic date: Viking age. Farm dated by potsherds and silver coins. Coll. by O. Espedal.

T-581. Risavika Rock Shelter I (a 1)

$2400 \pm 90$

450 в.C.

Charcoal from upper cultural layer which contained Iron age pottery.

T-582. Risavika Rock Shelter I (a 3)

$$
2040 \pm 90
$$

90 в.C. artifacts.

Charcoal from lower cultural layer which contained Stone age

\section{T-583. Risavika Rock Shelter II (D 10)}

$$
2000 \pm 80
$$

Charcoal from fire pit in cultural layer of maximum thickness 0.60 $\mathrm{m}$ in rock shelter. Found together with ceramics of Iron age type, arrow heads, and a shaft hole axe. Coll. by H. Hansen.

\section{T-619. Risavika Site 1 (Sq. H, I 21-22)}

$1710 \pm 80$

Charcoal from fire pit in site of boat house. Archaeologic date: ca. 500 A.D. Coll. by P. Rolfsen. Comment (O.M.): more detailed analysis of 
material shows different stages. Older house partly under wall between Houses 1 and 2 is clearly from 2nd or 3rd century A.D.

\section{T-621. Risavika Site 1 (Sq. H 13)}

Charcoal from middle of site.

\section{T-620. Risavika Site 2 (Sq. T 12)}

Charcoal from site of boat house. Archaeologic date: 0 to 200 A.D. Coll. by P. Rolfsen.

\section{Boat house series, Rogaland}

Charcoal from 2 boat house sites in Rogaland. Archaeologic date: late Viking age. Coll. 1960 to 1966 by several archaeologists at Stavanger Mus.; subm. 1967 by O. Möllerop. Comment: prior to excavation, boat houses of these types were considered of Viking age or Medieval period.

\section{T-646. Boat house (Sq. H 12)}

A.D. 870

$1080 \pm 70$

Charcoal from site 0.15 to $0.20 \mathrm{~m}$ deep in Köbenhavnerbukta, $\mathrm{N}$ Sunde, Stavanger, $\left(58^{\circ} 58^{\prime} \mathrm{N}\right.$ Lat, $5^{\circ} 7^{\prime} \mathrm{E}$ Long) Rogaland, Norway. Coll. 1966 by P. Rolfsen.

\section{T-647. Western boat house (S. 8692a)}

$$
\begin{array}{rl}
1300 & \pm 80 \\
\text { A.D. } 650 & 1810 \\
180 \\
\text { A.D. } 140
\end{array}
$$

T-648. Western boathouse (S. 8692b)

Wood from site in Nes, Karmöy, $\left(59^{\circ} 14^{\prime} \mathrm{N}\right.$ Lat, $5^{\circ} 53^{\prime} \mathrm{E}$ Long), Rogaland, Norway. Coll. 1960 by B. Myhre. Comment: as in Risavika series, older house underlies younger, partly under wall of younger one. Dates of these houses have been used as basis for dating $1.80 \mathrm{~m}$ shoreline to Viking age.

\section{Gauthelleren series, Hordaland}

Charcoal from rock shelter, Gauthelleren, at $+1000 \mathrm{~m}$ at Növlevannene, Odda, $\left(59^{\circ} 48^{\prime} \mathrm{N}\right.$ Lat, $6^{\circ} 56^{\prime} \mathrm{E}$ Long), Hordaland, Norway. Samples from very unhomogeneous cultural layer, mostly $0.60 \mathrm{~m}$ thick. Coll. and subm. 1964 by K. Odner, Historical Mus., Univ. of Bergen.

T-458. Gauthelleren 0.45 to $0.55 \mathrm{~m}$ depth.

T-485. Gauthelleren

0.35 to $0.45 \mathrm{~m}$ depth.

\section{T-487. Gauthelleren}

0.0 to $0.15 \mathrm{~m}$ depth.

Comment (K.O.): layer between 0.35 and $0.55 \mathrm{~m}$ contained artifacts
$1980 \pm 100$

30 B.C.

$$
1690 \pm 100
$$

A.D. 260

$270 \pm 90$

A.D. 1680 
of quartz, quartzite, and flint (flat arrowheads, dagger fragments, strikea-light stone, etc.). Earlier, these would have been dated to late Neolithic time (1800 to 1500 B.C.). From experience of other investigators (Lomborg, 1959; Schönbäck, 1950-51; Strömberg, 1954) it is not unreasonable that in geographically insulated places like Röldal, mentioned artifacts were still in use at birth of Christ. Layer between 0 and $0.15 \mathrm{~m}$ contained artifacts such as clincher nails and hones. Archaeologic date of this layer is in agreement with $\mathrm{C}^{14}$ age (Odner, 1965 and 1968).

\section{Ullshelleren series, Röldal}

Charcoal from rock shelter, Ulshelleren, at $+700 \mathrm{~m}$ in Valldal, Röldal, (59 $56^{\prime} \mathrm{N}$ Lat, $6^{\circ} 57^{\prime} \mathrm{E}$ Long), Hordaland, Norway. Coll. 1963 by I. Altern; subm. 1964 by K. Odner. Archaeologic date: older Iron age, 500 B.C. to 500 A.D.

\section{T-459. Ullshelleren}

$1610 \pm 90$ 0.95 to $0.99 \mathrm{~m}$ deep in layer with ceramics, flake of quartzite, etc.

\section{T-460. Ullshelleren}

$1700 \pm 90$

$0.30 \mathrm{~m}$ deep in layer with quartzite, artifacts, and iron slag. Comment (K.O.): archaeologic date gives ages between 200 and 600 A.D., which agrees with $\mathrm{C}^{14}$ age. Pollen analytic investigation and $\mathrm{C}^{14}$ measurements were made on peat from site (Hafsten, 1965, and this date list, T-447 to $\mathrm{T}-449)$. There is ca. $1000 \mathrm{yr}$ difference in age between peat and charcoal found in same layer.

\section{T-697. Heller II, Geiteryggen, Buskerud}

$1860 \pm 80$

Charcoal from Rock Shelter E of Geiteryggen, Hol, $\left(60^{\circ} 40^{\prime} \mathrm{N}\right.$ Lat, $7^{\circ} 40^{\prime} \mathrm{E}$ Long), Buskerud, Norway, 0.30 to $0.40 \mathrm{~m}$ deep, within area of $1 \mathrm{~m}^{2}$. Artifacts found belong to late Stone age and early Metal age. Coll. 1967 by A. Stalsberg; subm. by I. Martens. Comment (I.M.): finds are of same character as those from Vestredalshelleren (T-445, this date list), which is 3 to $4 \mathrm{~km}$ to NW. A sample from latter has been dated to $1890 \pm 90$ в.C., earliest possible date for archaeologic material. Lower time limit is uncertain, and more thorough treatment of this group of finds has not yet been done. Several radiocarbon samples (i.e., Bordalshelleren, T-217, Radiocarbon, 1964, v. 6, p. 289) have been dated to centuries around A.D., and there is no archaeologic evidence against such a late date.

\section{T-383. King Öystein seaport, Agdenes}

$1080 \pm 70$

Wood from $\log$ of timber found at Agdenes, örlandet, $\left(63^{\circ} 38^{\prime} \mathrm{N}\right.$ Lat, $9^{\circ} 46^{\prime}$ E Long), Sör-Tröndelag, Norway. Sample seems to derive from timber construction in a stone pier. Timber is visible at low water level. Coll. 1962 and subm. 1963 by S. Marstrander, Videnskapsselskabets Oldsaksamling, Trondheim. Comment (S.M.): according to relations of 
Snorre Sturlasson in saga of sons of King Magnus, King Öystein (1103 to 1122 A.D.) made harbor at outermost part of promontory of Agdenes, lying on $S$ side of mouth of Trondheimsfjord. Remnants of pier are on shore at inlet to little bay, which served as harbor.

\section{Soapstone and bog iron industries}

\section{T-685. Kleberbrudd, Lesja I}

$1170 \pm 80$

Charcoal from fire pit in 3 compartment house site, ca. $+1450 \mathrm{~m}$, soapstone quarries in Sjongsnabben Mt., Lesja, Opland $\left(62^{\circ} 15^{\prime} \mathrm{N}\right.$ Lat, $9^{\circ} \mathrm{E}$ Long), Norway. Coll. at depth $0.20 \mathrm{~m}$ in cultural deposit, consisting of soapstone debris, and fragments of soapstone pots. Coll. and subm. 1967 by A. Skjölsvold, Univ. Oldsaksamling, Oslo. Comment (see T-686).

\section{T-686. Kleberbrudd, Lesja IV}

$1150 \pm 80$

Charcoal from concentration (in fire pit) in house site ca. +1400 $\mathrm{m}$ and $400 \mathrm{~m}$ apart from T-685 near soapstone quarries below Store Horungen Mt., Lesja, (62 ${ }^{\circ} 15^{\prime} \mathrm{N}$ Lat, $9^{\circ} \mathrm{E}$ Long) Opland, Norway. Coll. among soapstone debris at depth $0.15 \mathrm{~m}$. Coll. and subm. 1965 by A. Skjölsvold. Comment (A.S.): T-685 and T-686 are 1st $\mathrm{C}^{14}$ dates obtained from Norwegian soapstone quarries of Viking age.

\section{T-687. Kleberbrudd, Kvikne}

$2350 \pm 90$ 400 B.c.

Piece of wooden spade from soapstone quarry in mts. W of Bubakk, Kvikne (62 ${ }^{\circ} 25^{\prime} \mathrm{N}$ Lat, $10^{\circ} 15^{\prime} \mathrm{E}$ Long) Hedmark, Norway. Found at depth $3 \mathrm{~m}$, buried by soapstone debris from prehistoric quarry. Coll. and subm. 1967 by A. Skjölsvold. Comment (A.S.): if date is reliable, it proves that use of soapstone for mass-fabrication of pots and vessels was fully developed in Norway by Celtic Iron age.

Traces in quarry show that thousands of vessels were manufactured at this spot. A 2nd charcoal sample from this quarry has been subm. for analysis for cross dating result.

\section{T-698. Bog iron, Neset}

$$
960 \pm 60
$$

\section{A.D. 990}

Charcoal from store close to melting furnace at Martinvika, Neset, Mösstrand, Telemark (59 $50^{\prime} \mathrm{N}$ Lat, $8^{\circ} 10^{\prime} \mathrm{E}$ Long), Norway. Coll. and subm. 1967 by I. Martens, Univ. Oldsaksamling, Oslo. Comment (I.M.): sample was close to outer wall of housesite in which there was a melting furnace. No datable artifacts were found. Site had been in use for a long time, and radiocarbon date lies within supposed time limits, max. 800 to 1350 yr A.D.

\section{Bog iron, Hovden, Telemark}

Samples from housesite at Hovden, Mösstrand, Rauland, Telemark $\left(59^{\circ} 50^{\prime} \mathrm{N}\right.$ Lat, $3^{\circ} 0^{\prime} \mathrm{E}$ Long), Norway. Samples T-506 and T-507 derive, 
respectively, from remains of roof and melting furnace for bog iron. Coll. 1963; subm. 1965 by I. Martens.

\section{T-506. Hovden, log of timber}

\section{T-507. Hovden, charcoal}

Comment (I.M): house cannot dated accurately, but has obviously been inhabited for a long time and bears signs of reconstruction. Archaeologic date: 12 th and 13 th centuries. Older logs may have been applied; melting furnace is presumably same age as house.

Date lists:

$\begin{array}{ll}\text { Copenhagen VI } & \text { Tauber, 1964 } \\ \text { Stockholm VI } & \text { Engstrand, 1965 } \\ \text { Trondheim I } & \text { Nydal, 1959 } \\ \text { Trondheim II } & \text { Nydal, 1960 } \\ \text { Trondheim III } & \text { Nydal, 1962 } \\ \text { Trondheim IV } & \text { Nydal, Lövseth, Skullerud, and Holm, 1964 }\end{array}$

\section{REFFRFNCES}

geol. undersökelse, no. $256,160 \mathrm{p}$.
Bakka, Egil, 1964, Steinaldergranskningar i Nordhordland 1960-63: Frå Fjon til Fusa; Årb. for Nord og Midhordland Sogelag, 17. årgang, Bergen, p. 3-36.

Dyck, Willy, 1965, Secular variations in the $\mathrm{C}^{14}$ concentration of Douglas fir trees rings: Sixth internatl. conf. on radiocarbon and tritium dating proc., Pullman, Washington, June 7-11, 1965, p. 440-451.

Engstrand, Lars G., 1965, Stockholm natural radiocarbon measurements VI: Radiocarbon, v. 7, p. 257-290.

Gjessing, J., 1966, Deglaciation of southeast and east central south Norway; Norsk geog. tidsskr., v. 20, p. 133-149.

Hafsten, U., 1956, Pollen-analytic investigations on the late Quaternary development in the inner Oslofjord area: Univ. Bergen Årb. 1956, naturv. R. no. 8, 163 p. 1965 , Vegetational history of land occupation in Valldalen in the subalpine region of central south Norway traced by pollen analysis and radiocarbon measurements: Univ. Bergen Årb. 1965, mat.-naturv. ser. 3, p. 1-26.

Hagen, Anders, 1960, Mesolittiske jegergrupper i norske höyfjell: Univ. Oldsaksamling Årb. 1960-1, Oslo 1963, p. 109-142.

Hansen, H. P., 1966, Sein- og postglasiale havniåer i Nord-Troms: M.S. thesis, Univ. of Oslo (unpub.).

Holmsen, Gunnar, 1955, Hallingdal; beskrivelse til kvartargeologiske landgeneralkart: Norges geol. undersökelse, no. 190, p. 1-55.

Holtedahl, Olaf, 1928-29, Om landisens bortsmelting fra strökene ved Trondheimsfjorden: Norsk geog. tidsskr., v. 2, p. 95-118.

1960, Geology of Norway: remarks on some western and northern parts of Norway: Norges geol. undersökelse, no. 208, p. 409-415.

Ingstad, Helge, 1959, Landet under Leidarstjernen: Gyldendal Norsk Forlag, Oslo. Martins Press, New York.

Kaldhol, H., 1912, Nordfjords kvartieravleiringer: Bergens Mus. Aarb., no. 3, p. 58-70.

Kigoshi, K., 1965, Secular variation of atmospheric radiocarbon concentration and its dependence on geomagnetism: Sixth internatl. conf. on radiocarbon and tritium dating proc., Pullman, Washington, June 7-11, 1965, p. 429-438.

Klovning, I. and Hafsten, U., 1965, An early Post-glacial pollen profile from Fläms dalen, a tributary valley to the Sognefjord, western Norway: Norsk geol. tidsskr., no. 45, p. 333-338.

Kolderup, C. F., 1908, Bergensfeltet og tilstötende trakter i senglacial og postglacial tid: Bergens Mus. Aarb. 1907, no. 14, p. 1-268 (German summary, p. 240-256).

Lomborg, E., 1959, Fladehuggede flintredskaber i gravfund fra icldre bronzcalder: Aarböger fòr Nordisk Oldkyndighet, Köbenhavn, p. 146-184. 
Mangerud, J., 1968, Breoscillasjoner og vegetasjonshistorie i senglacial tid i Bergensområclet: Geol. Fören. Förh., v. 90, p. 465.

Marthinussen, M., 1960, in: Holtedahl, O. (ed.), Geology of Norway: Coast- and fjord area of Finnmark, Norges geol. undersökelse, no. 208, p. 416-432.

1962, $\mathrm{C}^{14}$-datings referring to shore lines, transgressions, and glacial substages in northern Norway: Norges geol. undersökelse, no. 215, p. 37-66.

Moe, D., 1968, En pollen-analytisk undersökelse i Beiarn kommune, Nordland fylke: M.S. thesis, Univ. of Bergen (unpub.).

Nydal. Reidar, 1959, Trondheim natural radiocarbon measurements I: Radiocarbon, v. 1, p. $76-80$. v. 2 , p. $82-96$ r. 4, p. 160-182.

1965, Ten years trial and error with the CO. proportional technique in Trondheim: Sixth internatl. conf. radiocarbon and tritium dating proc., Pullman, Washington, June $7-11,1965$, p. 1-16.

Nidal, Reidar et al., 1964, Trondheim natural radiocarbon measurements IV: Radiocarbon, v. 6, p. 280-290.

Nygard, T., 1969, Begnadalen og Ådalens glasifluviale geomorfologi: M.S. thesis, Univ. of Oslo (unpub.).

Odner, Knut, 1965, Vivik ved Holmevatn på Haukelifjell: Viking XXIX, Oslo, p. $201-243$.

wegian Archaeol. Rev., Oslo, v. 1, p. 80-89.

Olsson, J., 1925, Kolvborr, ny borrtyp för upptagning av lerprov: Teknisk tidsskr., Stockholm, no. 55, p. 11-16.

Östrem, Gunnar, 1961, Nya metoder för åldersbestämning av ändmoräner: Ymer no. 4, p. 241-252.

1964, Ice-cored moraines in Scandinavia: Geog. Annaler, v. 46, no. 3, p. $282-337$. 1, p. $1-38$.

Rekstad. J., 1905, Iagttagelser fra terrasser og strandlinjer i det vestlige Norge: Bergens Mus. Aarb., no. 2, p. 35.

Salmi, Martti, 1965, Pcdiastrum alger i den mikropaleontologiska undersökningen: Norsk geol. tidsskr., no. 45, p. 156.

1968, Development of Palsas in Finnish Lapland: Third internatl. peat cong. Quebec, Canada, Aug. 18-23, 1968, p. 1-19.

Schönbäck, B., 1950-51, Bronsåldershus i Uppland: Tor 1950-51, Uppsala, p. 23-46.

Sollid, J. L., 1963-64, Isavsmeltingsforlöpet langs hovedvasskillet mellom Hjerkinn og Kvikneskogen: Norsk geog. tidsskr., v. 19, p. 51-76.

1969, A tree stump, presumably of spruce, from Würm Interstadial W I/II, found in Ringerike, South Norway, Norsk geog. tidsskr. (in press).

Strömberg, M., 1954, Bronzezeitliche Wohnplätze in Schonen, Medd. Lunds Univ. Hist. Mus., Lund, p. 295-381.

Suess, H. E., 1965, Secular variations of the cosmic-ray-produced carbon 14 in the atmosphere and their interpretations: Jour. Geophys. Research, v. 70, no. 23, p. $5937-5952$.

Tauber, Henrik, 1964, Copenhagen radiocarbon dates VI: Radiocarbon, v. 6, 1964, p. $215-225$.

Undâs, I., 1942, Fossilfunnet i Blomvåg: Naturen, Årg. 66, p. 97-107.

Willis, E. H., Tauber, H., and Münnich, K. O., 1960, Variations in the atmospheric radiocarbon concentration over the past 1300 years: Radiocarbon, v. 2, p. 1-4. 